\title{
Evolutions in estuary governance? Reflections and lessons from Australia, France and New Caledonia
}

\author{
Katherine A. Daniell ${ }^{\mathrm{a}, *}$, Roel Plant ${ }^{\mathrm{b}, \mathrm{i}}$, Victoria Pilbeam ${ }^{\mathrm{a}}$, Catherine Sabinot ${ }^{\mathrm{d}}$, Nicolas Paget ${ }^{\mathrm{c}, \mathrm{e}}$, \\ Karen Astles ${ }^{\mathrm{f}}$, Ruben Steffens ${ }^{\mathrm{a}}$, Olivier Barreteau ${ }^{\mathrm{e}}$, Severine Bouard ${ }^{\mathrm{g}}$, Peter Coad ${ }^{\mathrm{h}}$, \\ Anna Gordon ${ }^{\mathrm{a}}$, Nils Ferrand ${ }^{\mathrm{e}}$, Pierre-Yves Le Meur ${ }^{\mathrm{d}}$, Caroline Lejars ${ }^{\mathrm{c}}{ }^{\mathrm{g}}$, Pierre Maurel ${ }^{\mathrm{i}}$, \\ Ana Rubio $^{\mathrm{h}}$, Jean-Emmanuel Rougier ${ }^{\mathrm{j}}$, Ian White ${ }^{\mathrm{a}}$ \\ ${ }^{a}$ The Australian National University, Fenner School of Environment and Society, \#48 Linneaus Way Acton ACT 2601, Australia \\ ${ }^{\mathrm{b}}$ UTS - University of Technology Sydney, Institute for Sustainable Futures, Bldg 10, 235 Jones St, Ultimo, NSW 2007, Australia \\ ${ }^{c}$ CIRAD - Centre de cooperation internationale en recherche agronomique pour le developpement, Avenue Agropolis, TA 178/04, 34398 Montpellier Cedex 5, France \\ ${ }^{\mathrm{d}}$ IRD - Institut de Recherche pour le Developpement, Centre de Noumea, 101 Promenade Roger Laroque, BP A5, 98848 Noumea cedex, New Caledonia \\ ${ }^{\mathrm{e}}$ IRSTEA - Institut national de recherche en sciences et technologies pour l'environnement et l'agriculture, UMR G-EAU, 361 Rue Jean François Breton, 34196 \\ Montpellier, France \\ ${ }^{\mathrm{f}}$ NSW DPI - New South Wales Government Department of Primary Industries, Fisheries NSW, PO Box 5106, Wollongong, 2520, Australia \\ ${ }^{\mathrm{g}}$ IAC - Institut Agronomique Neo-Caledonien, Centre de Recherche Nord de Pouembout, B.P. 6 - 98825, Pouembout, New Caledonia \\ ${ }^{\mathrm{h}}$ Hornsby Shire Council, PO Box 37, Hornsby NSW 1630, Australia \\ ${ }^{\mathrm{i}}$ IRSTEA - Institut national de recherche en sciences et technologies pour l'environnement et l'agriculture, Universite de Montpellier, UMR TETIS, 500 rue Jean-François \\ Breton, 34093 Montpellier Cedex 5, Montpellier, France \\ ${ }_{\mathrm{j}}^{\mathrm{L}}$ LISODE - Lien Social et Decision, 2512 Route de Mende, 34090 Montpellier, France
}

\section{A R T I C L E I N F O}

\section{Keywords:}

Evolutionary governance

Estuary management

Boundary

Discourses

Risk perceptions

Information systems

\begin{abstract}
A B S T R A T
Estuaries are cradles of life for the communities who live around and within them. They are valued in multiple ways for the services they provide to humans, including food production, recreation, water purification, navigation and amenity. Various groups of stakeholders all place different importance on these values, how their needs and practices interact, and what it means to effectively manage an estuary towards a range of desirable goals. This typically creates value conflicts over how estuaries should be managed. Navigating such conflicts requires governance arrangements and methods that allow multiple parties to find a common path forward. Using Evolutionary Governance Theory (EGT) and a hybrid analytic framework incorporating aspects of multilevel/multi-scalar governance, risk governance and territorial intelligence theory, this paper explores the (co-) evolution of governance processes by analysing lessons learnt from action in and observation of estuaries in Australia (Lower Hawkesbury), France (Thau) and New Caledonia (Thio). A multi-method research approach to data collection was used and comparative analysis across the three estuaries undertaken to understand the evolutions in each of their governance systems. From this analysis, several reflections and lessons for the governance of other land-sea systems emerge on: the importance of boundary organisations and boundary negotiations in re-defining integrated approaches to land-sea governance; how particular information systems or models, as well as discourses from other key actors shape co-evolutions of estuarine governance; and that risks or shocks still appear to be the catalysers of new forms of collective action and major reconfigurations and evolutions of estuarine governance.
\end{abstract}

\section{Introduction}

Estuaries are cradles of life for the communities who live around and within them. They represent the meeting point where land-based water meets the sea: hybrid environments where specific ranges of salinity allows certain ecosystems, fisheries and human activities to develop. These estuarine social-ecological systems-that can be identified in different geomorphological forms from coastal lagoons to deltas [126]

\footnotetext{
* Corresponding author. Fenner School of Environment and Society, The Australian National University, \#48 Linneaus Way, Acton, ACT 2601, Australia.

E-mail address: katherine.daniell@anu.edu.au (K.A. Daniell).
} 
-are constantly evolving. Connectivity issues are compounded when catchments accommodate urban development and the land-sea environment itself is changing. For example, many of the processes controlling sedimentation and coastal erosion in estuaries are sensitive to climate change impacts (including sea-level rise, more extreme weather events and ocean acidification) [1,2], putting waterfront development, other infrastructure and adjacent communities at risk. Hybrid estuarine environments are valued in multiple ways for the services they provide, including food production, recreation, water purification, navigation and amenity [3-5]. For their inhabitants, they are also places vested with symbolic, customary and heritage values. First peoples, residents, oyster farmers, fishers, housing developers, tourism operators, farmers, shipping or transport companies, environmental NGOs and government agencies, all place different importance on these values. How their needs and practices interact, and what these interactions mean for effectively managing an estuary towards a range of desirable goals are key questions of estuary governance. Despite stakeholders all valuing and relying on the estuary differently, there are often knowledge gaps, perceptions and assumptions within community and management bodies around interacting values, needs and interests. For example, urban and rural upstream community members may not be aware of the impact they impose on downstream users such as estuarine commercial fishers or aquaculture industries. While a few agricultural communities would value, for example, using fertilizer and pesticides, downstream fishers would value healthy aquatic ecosystems. These stakeholders' practices are not necessarily in alignment.

Due to their hybrid land-sea nature, estuaries have typically been difficult to manage effectively with either land or sea-based governance arrangements [6,7]. Governance, in regard to the management of the estuaries, incorporates the fluid and ongoing discourse among actors, institutions and knowledge in decision-making processes and action, subject to systems of authority. The governance of social-ecological connectivities between land-based, sea-based and estuarine processes functions in theory and practice represents a major knowledge gap [8]. A solid, bespoke theoretical foundation for the management and governance of multi stakeholder relationships in estuaries and coastal areas is currently lacking [9-11]. As the effects of climate change unfold, the call for estuary governance theory will only get stronger: climate change has no jurisdictional or bureaucratic boundaries and will increasingly alter the natural systems contained within estuarine systems $[12,13]$. For this reason, further advancement of estuarine governance theory will specifically need to address co-evolution.

Estuaries do not easily fit within legally or culturally prescribed categories around land and sea, as there are often other coherent settlement, mangrove, inlet or fishing ground areas that may instead be the focus of local community management. Estuaries often span multiple jurisdictions and biophysically belong to catchments and river basins, as well as to coastal areas and bio-regions. This makes defining the appropriate scales and levels for developing governance arrangements far from evident (e.g. Refs. [14-16]). As such, they often escape the attention of decision-makers as an entity to be specified and governed accordingly. This leads to multiple jurisdictions being responsible for various components of an estuarine landscape. For example, in New South Wales, Australia, until recently mean high water has been used to mark the boundary for estuaries in legislation for various authorities (e. g. Crown Lands, Coastal Protection Regulations and National Parks and Wildlife Acts). However, many intertidal habitats such as saltmarsh and mangroves exist above the mean high water limit. Consequently, management of human activities above mean high water but outside the land boundary of either private or public land fell into an ambiguous space. Changes to land planning instruments made in NSW in 2016 now allow for land-based zonings to be applied on waterways to ensure consistency when zoning these communities, eliminating the 'governance limbo' that had previously existed. From this example we can infer that 'estuary' as a category may itself not reflect the ways that local communities understand or use their landscapes, or even fit local people's representations in terms of life-world, place-making, uses, and property rights.

Regardless of the categorisation of these hybrid land-sea places, there is an increasing realisation of the interdependence of actors' behaviour and other socio-environmental risks affecting many estuaries and other coastal hybrid zones such as lagoons, coastal lakes, mangroves, deltas and coral reefs $[17,18]$. Specifically, there is increasing acknowledgement that greater integrated management and governance is required to effectively protect the aforementioned values of these special places $[9,19]$. Therefore, over the past decades, there has been increasing experimentation worldwide in developing management and governance regimes to deal with these challenges (e.g. Refs. [20-22]); see also [23]. Advancements in the biophysical sciences have offered estuary managers and stakeholders a better understanding of estuarine processes, including through fluid dynamics; water quality modelling; and population dynamics studies for various marine species (e.g. Refs. $[24,25])$. In addition, integrated research, using such conceptual and theoretical framings as 'social-ecological systems' and 'socio-technical arrangements', is increasingly being undertaken to engage and assist local communities and other actors. Specifically, managers and other estuary community actors are developing innovative hybrid science-management and co-production processes. These harness a wide range of methodologies and structures for managing activities in estuaries as well as for whole of estuary management. An example in the first category is Chesapeake Bay in the United States. For this estuary, processes of consensus conference modelling focussed on fisheries evolution and management, as well as oyster futures have been facilitated between industry representatives, managers and scientists (e.g. Refs. [26,27]). An example of innovative whole-of-estuary governance can be found in the Thau Lagoon, Southern France. Here, both low-tech and high-tech information tools have been developed and brought together to support different groups of stakeholders (e.g. Refs. [28-33]). Many such co-production processes have led, either by design or through eventual collective learning processes, to alterations in governing processes.

Conversely, actors in other estuarine systems are yet to coalesce around the concept of estuary governance. They have yet to find the resources and develop the structures of collective action necessary to provide effective governance in these interconnected places. In most estuaries, relational networks, information and data streams appear to be lacking, so there is little support for collective action. For example, socio-economic value of estuarine-related commercial industries like fishing and aquaculture is often absent. Without this data and information, there is little recognition of the significance of these industries for regional towns and areas. Studies focusing on multiple socioeconomic values associated with commercial fishing and aquaculture are now emerging (e.g. Refs. [34,35]), and the next step will be to integrate insights from this work into collective decision-making for more effective management of the hybrid estuary environments.

The changing nature of estuary governance and a push towards greater experimentation requires an understanding of how actors, institutions, norms and knowledge around estuaries co-evolve. It also requires an understanding of how some of these elements have been made visible or invisible through policy, science, the strategies of other actors and institutional designs. One theory that can help with building this understanding is Evolutionary Governance Theory (EGT), which is premised on the idea that change does not occur randomly within a governance system, but rather as the result of co-evolution of different systemic elements [36]; see also [37]. Under such a theoretical lens, it is possible to understand the way that context has previously shaped estuary governance and how it is key to predicting how governance can and is evolving to encompass a full range of land-sea interactions. As previously discussed, adequately defining and managing boundaries is a complex problem for estuarine governance. EGT in the context of estuaries, sees boundaries as adaptive and constantly evolving physical and non-physical spaces, objects and subjects: a conceptual framing that, once applied, is likely to advance understanding of estuarine governance 
through empirical observation. EGT also distinguishes between different types of dependencies in evolving governance systems: path dependence; inter-dependence; and goal dependence. EGT provides a theoretically diverse toolkit for addressing the evolution of governance systems [36, 53]. Within this toolkit operates a process-oriented and interactionist conception of governance that helps to avoid overlooking the conjunctural and political dimensions of governance as a more or less stabilised set of rules and regulations resulting from the repeated interplay of state and non-state actors and institutions around a public issue [38]; see also $[39,40]$. Thus, from an EGT perspective, governance can result in (dis)order in unexpected ways and according to patterns that are easier to analyse than to predict.

This paper explores how a diverse range of estuary governance processes have evolved under differing local conditions. Through an EGT lens, it will specifically examine the roles that information and coordination, connected with other factors such as changing discourses, have had on three selected estuaries around the world: the Lower Hawkesbury Estuary in Australia, the Thau Lagoon in France and the Thio Estuary in New Caledonia.

The next section of the paper outlines the theoretical framework and methodology. Results and discussion are then presented by means of comparative case studies and discussion of implications for theory and practice. From this comparative analysis, the paper draws conclusions for both the generic governance of estuaries as crucial 'nexus' spaces for land-sea interactions, and the advancement of EGT.

\section{Analytical framework and methodology}

\subsection{Framework}

To examine how estuary governance processes evolve, a hybrid analytical framework based on Evolutionary Governance Theory (EGT) was developed (Fig. 1). This framework focuses on the co-evolution of actors, knowledge and institutions, combining elements of multi-level/ multi-scalar governance theory [16,41-43]; risk governance theory [44-46] and territorial intelligence theory $[29,47,48]$.

The framework accommodates epistemological pluralism, as EGT, consistent with Ostrom et al. [49]; sees governance as the contextualised 'umbrella' process that continuously restructures the organisation of relations between actors both human and non-human. The latter can include models, discourses and infrastructure, as per Latour and colleagues, in a contextual environment [50-52]. Such governance processes thus emerge from interactions within this changing environment, new actors and institutions and are path-, inter- and goal dependent. Therefore, EGT places specific emphasis on 'co-evolution', specifically between actor/institution and power/knowledge configurations through an understanding of path dependencies [46].

In EGT, governance is seen as socially constructed and choices about governance pathways as strongly related to narratives: "it takes a narrative, the creation of a narrative, to see the unity of a community" [53]: 23) and discourses that actors and institutions create and can subsequently relate to. Those narratives dictate knowledge seeking and artefact creation (which in return contribute to the evolution of the narrative). Artefacts, which for [51] also include non-human actors, are objects and narratives participating in the global evolution of governance. Building those objects and narratives has a performative effect that may trigger changes in governance evolution. Narratives may rely on objectification (a science-validated direction), naturalization (governance goes in nature's direction: where Nature's will, or let say autopoiesis, is human-built and interpreted) or even specific myths and stories. Although causality within policy narratives may appear simple at times, within EGT, causality is complex to determine due to the centrality of retroaction and recursion and emphasis on unpredictable events [36].

From under this broad EGT umbrella, the framework focuses on three key aspects of estuarine governance, drawing on areas of insight from complementary theoretical lenses.

First, multi-level and multi-scalar governance is drawn on since it allows specific investigation of the scales and levels across which the aforementioned organisation of relations occurs, and in particular potential areas of misalignment, cross-scale interactions and interplay [15, 16]. Specifically; the spatial, administrative, institutional, stakes/issues and temporal scales are looked at in detail, although others, such as the management and knowledge scales are of course also relevant but not discussed in depth. To what extent resources are shared or are in competition between actors at different administrative or institutional levels is also considered [41,49].

Second, territorial intelligence theory is drawn upon to examine the specific coordinative roles of Information and Communication Technologies and information flows between actors in governance $[48,54,55]$. Specifically, what roles non-human actors like models, information systems and discourses play in shaping evolutionary governance processes is

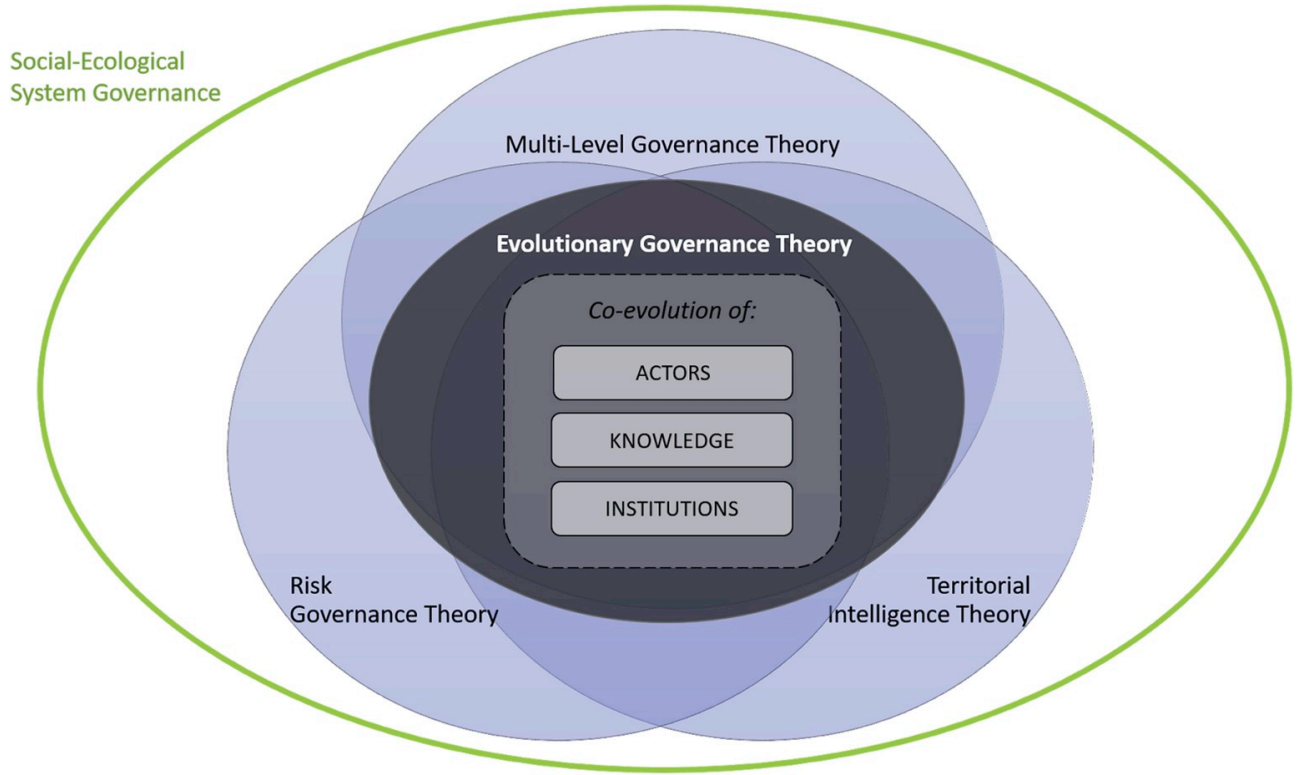

Fig. 1. Conceptual analytical framework for studying estuary governance evolutions. 
examined.

Thirdly, risk governance theory is drawn on to understand estuarine communities', managers' and stakeholder beneficiaries' perceptions of risks [45,56,57]; ISO31000/ISO31010). Specifically, the interdependencies of their knowledges, power structures and associated conflicts within estuarine contexts, and how this fits with wider discourses, EGT's stress on contingency and controversies around estuary governance, is explored.

Using this hybrid framework, represented in Fig. 1, a comparison is drawn contrasting a number of cases in order to draw lessons for evolutionary governance. This creates a means of navigating hybrid estuarine environments in more desirable directions.

\subsection{Methodology}

This study applies a multi-method approach to data collection, including through action and observation of professional work and interviews. In all instances, either participatory intervention research [58, 59] and/or ethnographic/qualitative methods [60] were used to understand the governance and connected social-ecological processes. A case study approach [61] was used to allow comparative empirical analysis of co-evolving estuarine governance processes. Each case had multiple researchers who can be considered as participatory or professional 'actors' in the cases through either being direct managers of estuarine environments or researchers who have supported and published studies on them at certain points in time, which in turn acts to shape discourses related to their governance.

The primary data collection methods used during times of research and/or management intervention (see Table A2. in appendix) in each case over the past two decades ranged from direct participation in and observation of management and planning meetings, interviews and ethnographic fieldwork, as well as existing documentation searches and analysis (e.g. of published and unpublished reports, papers and theses). Publications on individual cases involving and outlining the methods of this primary research include: $[31,59,62-73]$ in the Hawkesbury; $[2,4$, 29,33,48,74-80,125] in Thau and [81-86,124] in the Thio. In addition to publications, a meta-dataset was compiled based on the collection and collation of expert knowledge developed through professional in-region experience, workshops, conference attendance and other professional and academic activity (see Table A2). Data collection was guided by a proforma with three main sections that were informed by our analytical framework: i) scales and levels (location, topography; levels of governance; institutional mechanisms; natural assets; planning context); ii) roles and information flows (stakeholders/beneficiaries; history; information sharing); and iii) actor perceptions and discourses (focal interests; influential discourses; future development; efficacy of governance; implementation requirements), as provided in Table A1. The paper's co-authors then engaged with this proforma and provided consolidated information based on their respective areas of expertise and experience (see Table A2).

The completed meta-dataset and, where required, further targeted document analysis was then used to develop a comparative analysis of the three case studies. This was done by means of iterative interrogation and triangulation. Researchers from other case studies questioned and probed their colleagues on meanings and interpretations under each of the section headers. This eventually drew out a consensus regarding themes that warranted further exploration through additional literature review and discussion amongst co-authors. The four discussion themes that were agreed upon were: $i)$ boundaries; ii) levels of governance; iii) risks; and iv) collective action.

\section{Cases and scope}

This paper addresses three comprehensive cases of estuarine (or coastal lake) governance: the Lower Hawkesbury Estuary in New South Wales, Australia; the Thio Estuary in the Southern Province of New
Caledonia; and the Thau Basin and Lagoon in the Occitanie region of France. These estuaries jointly represent a diversity of governance processes, embedded in different legal, institutional and environmental contexts. The cases were chosen as one or more authors of the current paper had been involved in their study and/or management for a number of years. This long-term involvement provided access to relevant data for comparative analysis as previously noted. In addition, some authors have knowledge across these case-studies, to ensure consistency in cross-case analyses and interpretations. Each of the physical, governance and community asset contexts is introduced in the following subsections. Comparative case analysis and discussions then follows in Section 4.

\subsection{Lower Hawkesbury Estuary, NSW, Australia}

The Lower Hawkesbury is a semi-mature, tide dominated, drowned valley estuary, located on the northern edge of Sydney on the east coast of Australia. Governance in the Lower Hawkesbury is provided through community (farming, fishing, boating, representatives on management committees); local government councils, regional committees (Lower Hawkesbury estuary management plan committee); state government (fisheries, owner of water agency Sydney Water, Local Land Services (LLS)) and the Federal Government (EPBC Act). Institutional mechanisms are in place at each level of governance to regulate and manage the Lower Hawkesbury, including: Lower Hawkesbury Estuary Management Committee, Local Environment Plans (LEPs), Development Control Plans (DCPs), EPBC Act, NSW Environmental Planning and Assessment (EPA) Act, 1979, State Environmental Planning Policy (SEPPs), Regional Environmental Plans, Water Management Act 2000, National Parks and Wildlife Act 1974 (NSW), Local Land Services Act 2013, Environment Operations Act 1999, Threatened Species Conservation Act 1995 and Fisheries Management Act 1994.

The Lower Hawkesbury is used for both recreation and industry with its assets including oyster farming, fishing (passive and engine), boating \& water activities, recreation (recreational swimming sites), scenic amenity, adjoining land-based urban development, bird watching (migratory birds). The included landscape encompasses beaches, seagrasses, mangroves, mudflats, freshwater holes and wetlands. Boundaries for institutional planning extend to the lower river basin including tributary catchments (but exclude coastal catchments). Management focuses on a multi-risk structure (incorporating physical, governance, economic factors) however the main ability for implementation is through local government mechanisms.

In terms of physical land-water interdependencies, the Lower Hawkesbury's water quality and downstream activities such as oyster farming and recreational uses are largely impacted by upstream agricultural run-off, as well as urban pollution [122].

\subsection{Thio Estuary, New Caledonia}

The Thio River Estuary is located in the Southern Province of New Caledonia on the mouth of the Thio River, $180 \mathrm{~km}$ from Noumea. Administrative scales of governance on the Thio is operated by Southern Province Community/local associations; Southern Provincial Government and the New Caledonian government which is responsible for the protection and prevention of pollution. Freshwater management in the Thio partially depends on French municipalities' code, excluding rights on customary land. The governance of Thio rests with the government of the Southern Province (which encompasses the entire river). There has been an increasing push for local governance. The indigenous and clanbased Kanak dimension came to the foreground in 1996, and more recently in the negotiations about the possible restart of mining in the southern part of Thio (called 'the forgotten coast') and after two important rain events in 2013 an interethnic association 'Chava xua' was formed.

The Thio is rich in natural resources. Its principal uses and value are 
in nickel mining (nickel extraction is very water intensive), land-based urban development, local agriculture and small fisheries. Water also has an important cultural value to local Kanak tribes. Furthermore, water from the Thio is a concern for local environmental NGOs as a buffer for extreme weather events (drought and cyclones). Institutional planning applies to the extended basin, reefs, catchment industry regulation including mining, agricultural soils and freshwater management.

The evolution of the Thio Estuary is closely linked to the nickel mining industry and its related ecological impacts. Adding to these issues, Thio also faces extreme water variability ranging from droughts to flooding, increasing numbers of informal settlements on its slag fills and beaches, and hyper-sedimentation of both the river itself and nearby coral beaches.

\subsection{Thau Lagoon, France}

In the South of France (Languedoc-Roussillon), the Thau Lagoon is a stream-fed semi enclosed karstic lagoon connected to the Mediterranean Sea by two small inlets. Administrative scales of governance incorporate community (fishers and oyster farmers), municipal governments (15 different townships) responsible for urban development planning, intercommunalities (unified representation for these 15 townships) and their engineering structure (SMBT), regional and national (regional and state planning directive) and European (Natura 2000). Institution mechanisms used in the governance of the Thau Lagoon include DCE (Water law), SAGE (water plan co-built with important local stakeholders), SCOT (which is an integrative land planning and management tool and encourages the increasing urbanisation of already urbanised areas in the south of the basin such as Sete, Frontignan, Balaruc-lesBains) and the conservation of natural and agricultural spaces in the northern part of the basin, CGI (pluriannual actions plan), Natura 2000 (biodiversity/conservation), SMVM (coastal land use regulation) and SLGRI (flood protection).

Thau Lagoon's natural assets and uses encompass oyster farming, fishing, agricultural activities (viticulture, horticulture and livestock farming), thermalism, natural environment of the garrigues (hiking, hunting), tourism (picturesque towns and villages, particularly Sete), scenic landscape, some leisure boating, local produce (Picpoul de Pinet with oysters) and beaches. Collective management of the estuary covers most of the basin and near-sea area, including urban development and redevelopment.

The Thau Lagoon is strongly marked by a progressive shift away from agriculture to more urban pressures on water quality and associated complications to planning and development.

\section{Case study insights and comparative analyses}

Having introduced and described the scope and context of each of three case studies, the current section analyses the range of coevolutionary pathways and possibilities that hybrid estuarine regions may face. The analysis is based on the detailed meta-dataset as compiled from the authors' knowledge of and experience with the respective cases (see Table A1. in Appendix), and the subsequent iteration and triangulation of this dataset which led to the identification of the four discussion themes that provide the structure of the current section: $i$ ) boundaries and interdependencies; ii) complex multi-level governance; iii) risks; and iv) collective action.

\subsection{Discussion theme 1: boundaries and interdependencies in evolving estuary governance}

Through analysis of three estuary cases, the fluid (re)delineation of system boundaries and 'boundary spaces' and the changing interdependencies that this creates was examined. Refs. $[87,88]$ originally coined the term 'boundary work' to describe the process through which boundaries are established between science and non-science. However, as [36] note, in governance "all boundaries are conceptual boundaries that delineate objects, subjects and places". As an extension of this, all governance boundaries can be seen as the result of boundary work: the (re)drawing, maintaining and negotiation of boundaries by interacting actors (see also [89]. This estuary governance analysis illustrates that even governance boundaries that seem 'naturally' grounded in geographical space are the result of continual and evolving boundary work underpinned by changing governance, actors and their interactions. Processes of negotiation between actors expand and contract boundaries and these boundaries, in turn, shape the kind of management interventions available to actors [90]. Further scrutiny of the selected case studies sheds light on how and why different boundary spaces evolve over time, including in response to environmental pressures, conceptual priorities and the evolution of cultural landscapes.

The Lower Hawkesbury case illustrates that bottom-up governance change in response to environmental pressures can reconstruct boundary spaces through the mutual recognition of interdependencies. For example, the Lower Hawkesbury estuary initially operated as a boundary between local government jurisdictions. The estuary was seen as the end of the physical scope of responsibilities for its adjacent local governments. A common space linking the in-water boundaries of these jurisdictions was thus managed (or rather left unmanaged - see white areas in Fig. 2) by jurisdictions with only partial responsibility over the water body. However, with community members and managers acknowledging that this governance arrangement limited their ability to manage the estuary (i.e. a boundary space as a whole entity), they embarked on a planning process outside of established state government processes. This resulted in a demand for local governments to go beyond local estuary management committees which, in 2007, only covered two small parts of the estuary's spatial extent (Brooklyn and Berowra shaded areas in Fig. 2). Instead, a new boundary spanning planning process was based on the Australian and New Zealand Risk Management Standard, to work together above and beyond their jurisdictional responsibilities, creating a higher level estuary management committee [91], as well as a newly acknowledged estuary and catchment-wide boundary within which they had shared governing responsibility. The work of the committee was formalised through the local governments gazetting the plan (e.g. passing into official local government policy). For this reason, it still relies on largely local resources to manage the collective work.

In the Thau Lagoon case, different instances and institutions of planning authority, each with their own management priorities, have created 'issue-based' boundaries which impact the governance of the estuary (see Fig. 3). For example, land use planning is governed by the Territorial coherence scheme, 'SCoT' in Fig. 3; water planning by the Water management and planning scheme 'SAGE' in Fig. 3; marine planning by the Scheme for valuing the sea, 'SMVM' in Fig. 3; and biodiversity by the Natura 2000 European biodiversity conservation plans. Additional responsibilities reside with a collection of local municipal governments or 'communes' in Fig. 3 [92]. This highlights the importance of conceptual or thematic boundaries, which frame what is important in estuarine governance. Indeed, each of the groups responsible for and involved in these planning schemes construct and perpetuate different discourses about what impacts the lagoon and how it can be managed. Examples of such (often overlapping) discourses include: 1) the importance of conservation spaces and buffers for improving runoff quality; 2) controlling population growth distribution in the whole basin and subsequent pollution though development restrictions; and 3) limiting boat traffic and direct pollution in the estuary. The development of such discourses leads to the involvement and interest of different stakeholders, which in turn creates a potential need for the State to prioritise resources between management actions that may all lead to similar water quality outcomes.

The analysis of the Thio estuary in New-Caledonia points to how 'images of history' can shift and harden the boundaries around estuaries. Van Assche et al. ([53]: 39) refer to 'images of history' as historical 


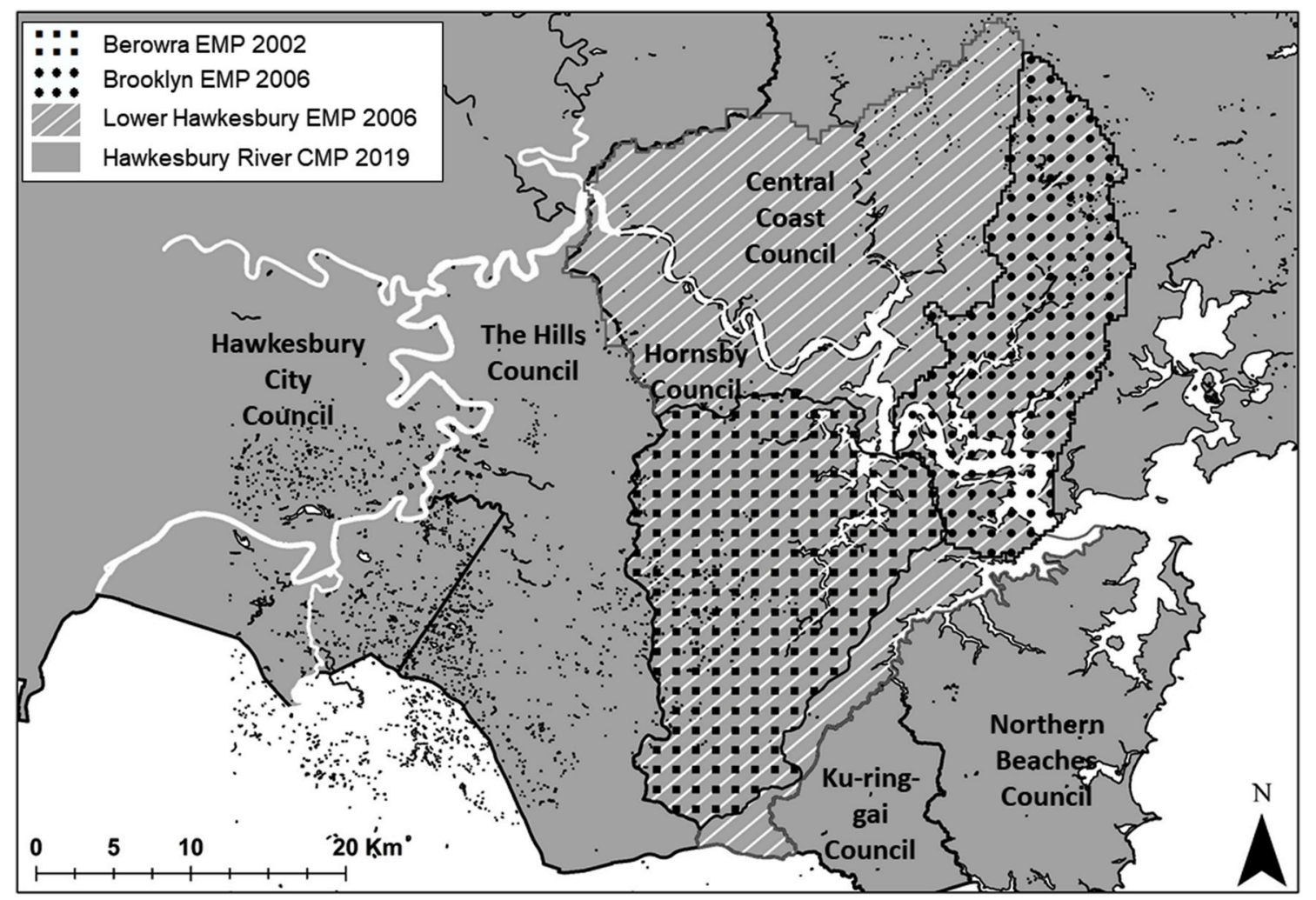

Fig. 2. Map of evolutions in Hawkesbury River estuary governance jurisdictions.

narratives or discourses that shape what actors consider the status quo. Analysis of the Thio estuary study highlights the power of industrial actors in shaping these 'images of history'. The Thio estuary landscape reflects a progressive sedimentation of historical events, such as missionary colonisation, mining development (nickel extraction including processing in the interwar period, and latter de-industrialisation), and the general settlement history including the permanent settlement on slag fills (quasi polder) of Kanak people from Borendy, East of Thio. Through the debate over this space and its boundaries, Thio's governance is subject to different instances and institutions of planning authorities. In particular, the evolution of Thio's governance remains closely intertwined with the nickel mining industry (now the SLN company, a subsidiary of the ERAMET French group) [83]. This is in part because SLN established a presence in Thio 140 years ago. SLN has both physically and discursively shaped the boundaries around the Thio estuary: people have settled on their slag fills, communities rely on their profits and service provision, and their sedimentation and efforts to mitigate sedimentation are directly changing the landscape [83]. Though SLN's image of history may generate inertia, other competing narratives are shifting the boundaries within and around the Thio estuary. For example, within Kanak culture, the coastline is not perceived as a boundary but rather as part of an interconnected whole stretching from ridge to reef [93]. This is different from the governmental representations which provide the framework for SLN's operations where the coast is seen as a boundary under governmental and provincial rules. These conflicting definitions create legitimacy issues on sea-land territories, which then often become subject to debate [93]. In a wider sense, since the 1970s, the environmental consequences and risks of mining activities to local populations, as well as the estuarine and nearby reef ecology, have become increasingly visible. This has led to mounting debates and claims from customary landowners (themselves narrowly related to the rise of a pro-independence Kanak movement), Thio township residents, as well as academics and environmentalists, that such risks require improved governance systems and a more holistic understanding of land and sea interactions.

Thus, all three cases demonstrate how boundary organisations and negotiations between different actors, discourses and spaces in each estuarine region are key in re-defining and re-shaping integrated approaches to land-sea governance.

\subsection{Discussion theme 2: complex multi-level governance in estuaries}

The discussion of estuary boundaries above also showed that governance of (at least some) estuaries involves complex multi-level governance arrangements. These different levels and the spatial scales at which they operate are themselves products of discursive processes [53]; specifically, a variety of forms of continuous negotiation in and between groups of actors [42,43,94]. The internal complexity of governance and the scope of its ambitions often increases over time [36] but also naturally leads to functional differentiation [53]: a process by which multi-level governance system negotiations are broken down into new differentiated subsystems to match contextual needs. However, if this complexity leads to perceived failures of governance in one or more of the subsystems, it opens windows of political opportunity for (sometimes radical) changes to the governance structures and systems of functioning, often purposely reducing or increasing functional differentiation $[95,96]$. The scope of governance evolution in such complex systems, of which estuaries represent an instance, is then linked to three key factors: 1) the relationships and negotiations between jurisdictions (linked to the discussion on boundary spaces in the last section); 2) actor interests, issues and values (what ought to be managed, by whom, and for what reasons); and 3) power and resources, including knowledge, finance and an ability to capture or develop discourse and effective negotiating strategies. The following section will focus on the first factor (relationships and negotiations). The two other factors will be expanded on in later sections.

An example of complex multi-level governance arrangements is the implementation of management strategies for coasts and estuaries in 


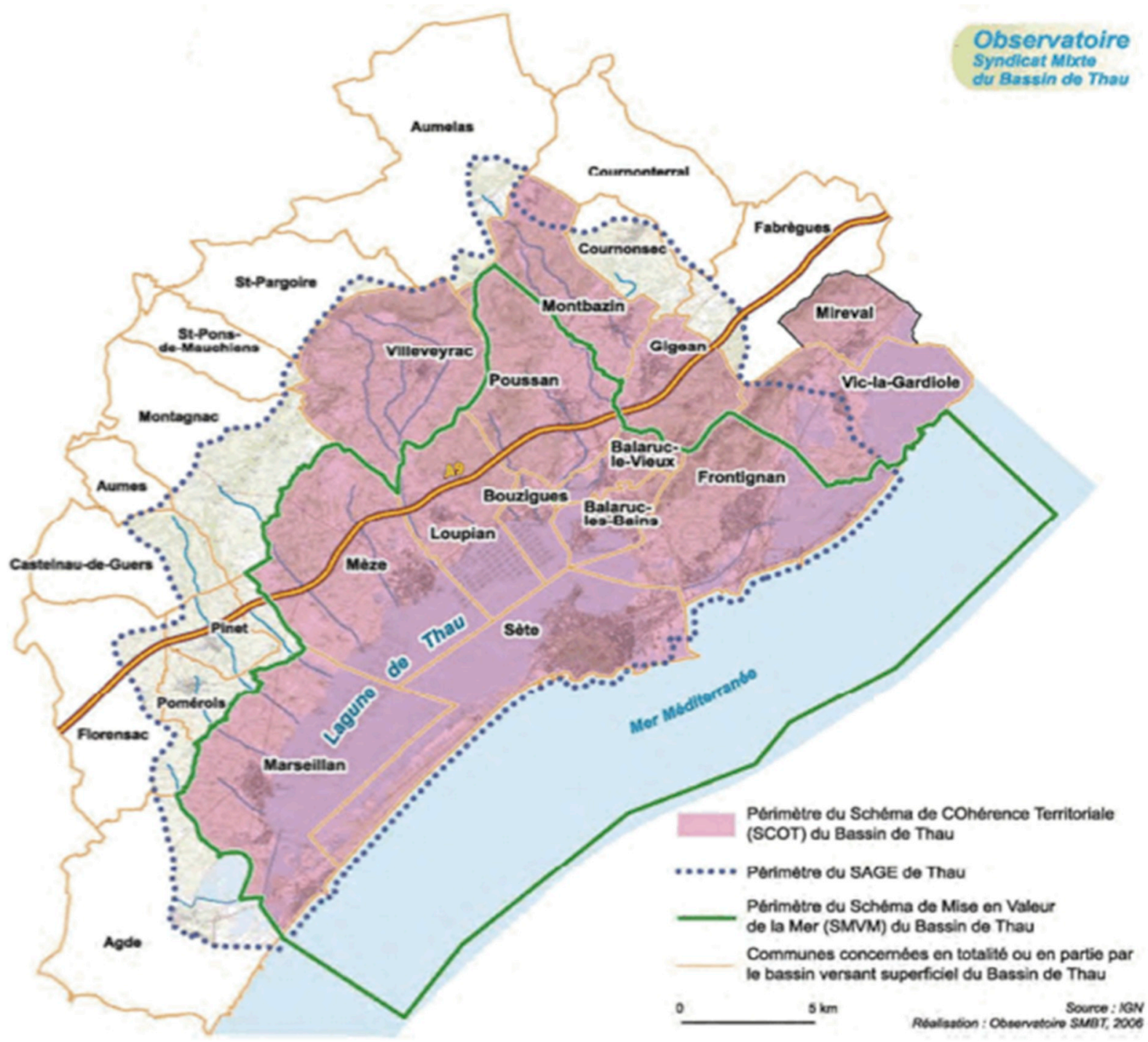

Fig. 3. Map of the Thau Basin and its overlapping sectoral jurisdictions.

Australia. These usually occur at local and regional spatial/administrative levels because local councils, or a group of local councils, have the responsibility for on-the-ground management of the environment. However, their management efforts are complicated by having jurisdiction over only part of an estuary or coastal area, within their governance boundary. In highly urbanised estuaries and coastal areas, where human uses are intensified, there are often multiple and interacting layers of governance, combined with diverse community and stakeholder groups (e.g. Refs. [6,97]). For example, in the Lower Hawkesbury Estuary (Australia), there are several complex and interacting layers of governance with jurisdiction over the estuary. Three local governments, four state government agencies and an overarching state marine management authority are responsible for implementing state and federal legislation and policies that impact the management of marine ecosystems and biodiversity [98], in addition to addressing local and regional issues. Implementation of the Lower Hawkesbury Estuary Management Plan alone has 10 agencies, including a water authority, responsible for its implementation [91]. Furthermore, multiple industry stakeholders, Indigenous and local community groups interact with these different layers of governance [91]. Therefore, there is no single agency or community group with sole responsibility for the natural resource management of the whole estuary, which is typical of urban estuaries within Australia $[6,80,99]$. The complexity of this governance context makes implementing management and research actions to sustain marine biodiversity consistently across a whole estuary or coastal area extremely challenging [99,100].

One way of navigating the complexity of these multi-level land-sea governance systems is through the coordination of brokering organisations. Similarly, to the Australian case, overlapping arrangements are found in Thau (France), where multiple municipalities, departments, regional and State-level planning schemes and legislation underpin complex responsibility arrangements for different aspects of the lagoon and its contributing hydrological basin and seaways. In addition, in Thau, as in other coastal zones where there is important listed biodiversity (of either national or international importance), local or regional planning arrangements are also subject to national legislation or international agreements (e.g. the European Natura 2000 directive or Environment Protection and Biodiversity Conservation (EPBC) Act 1999 in Australia). With responsibilities spread across many of these groups and other stakeholders, efforts have been made to better coordinate the key decision-making groups across levels and issue areas through the development of a brokering organisation, the SMBT (mixed syndicate of the Thau Basin). This arrangement is novel in that it coordinates land, water, sea, as well as biodiversity planning, through a range of tools, information management and diffusion strategies (see next section). The SMBT facilitates interactions between both planning-level stakeholders 
and groups with specific estuary interests (e.g. around specific seagrasses, see Ref. [29]. Its success as a key brokering agency has been evidenced by the French State giving it further formal responsibilities in recent years for coordinating flood planning and storm early warning across the Thau territory [101]. While [102] recognise the important role of knowledge brokers in complex evolving governance systems, the SMBT example additionally illustrates the wider role of brokering organisations in navigating complex multi-level processes.

Even in complex multilevel governance systems, with multiple jurisdictions and interests, powerful actors are better equipped to shape the evolution of estuary governance. As in all New-Caledonian settings, public, private and customary lands divide the Thio estuary [103]. Though the Thio estuary and its adjacent small urban settlement and other inhabited lands (3287 people in total in the 2014 Census) are subject to New Caledonian provincial and French federal regulations, the major driver of its governance has been the role of the mining industry, led by the SLN company [83]. SLN's operations have been integral to the development of the township, including the company's role in the transformation of the estuary environment and its management. Through employment and services provided to the local community, SLN has always been a key stakeholder, and indeed a major shaper, of territorial governance. In this case, because of the disproportionate amount of power SNL holds as a stakeholder or actor, it almost single-handedly shapes the risk acceptance profile. This represents an instance of a broader observation, which is that with more varied stakeholder perspectives the risk acceptance profile tends to get more diverse and potentially requires more elaborate processes to get stakeholders to express perceived risks and evaluate them from their respective perspectives. A single industrial actor having such a pivotal role in estuary governance suggests a particular mode of risk acceptance and risk taking. This element will be explored in the next section.

\subsection{Discussion theme 3: risks and their governance}

$\operatorname{Vo} \beta$ [37] describes evolutionary governance as 'a mode of governance which is reflected in strategies and institutions for collective action that can be characterized by the principles of adaptiveness, integration and anticipation'. All of these dimensions require governance systems to absorb and react to shocks or the underlying risks associated with them. The above analysis of boundaries and governance complexity demonstrates the importance of actor interests in and discourses around potential risks (e.g. poor water quality, impacts of mining, destruction of local livelihoods and customs). Specifically, risks-and other threats or realised shocks-catalyse opportunities for important co-evolutions in both informal and formal governance arrangements for estuarine and associated land and sea management systems. Although when seen through an evolutionary governance lens, governance systems are continually reconfiguring, it is often in moments of crisis that configurations assert themselves more fully and that their underlying patterns and processes become more apparent [36]. The study of 'crisis events' as pivotal moments can transform the way collaboration between actors occurs, information is developed and used and governance systems are adapted to better manage these risks and to promote resilience. $^{1}$ This is to say that crises are, and should be, distinguishable from slow and moderate risks due to the difficulty of being identified and avoided. This is because they are new and often (initially) invisible. Ulrich [44] offered a typology of risk societies, distinguishing between i) Pre-modern; ii) Early Modern; and iii) Late Modern. In regard to The Lower Hawkesbury, Thio and Thau, the latter modality of risk is clearly relevant to the design of evolutionary

\footnotetext{
${ }^{1}$ One increasingly common discourse and (re)framing of debates in risk governance and societal capacity to address these. See Ref. [118] for an up-to-date review of the resilience discourse(s) and application of theory to governance practice.
}

governance approaches, which is the focus of the following analysis. Thus, the following section explores how different estuary governance systems have reacted and reorganised differently in response to risks and shocks.

In 2004 in the Lower Hawkesbury, by "wiping out" the local Sydney Rock Oyster (Saccostrea glomerata), the QX oyster disease catalysed a collaborative reorganisation of estuary governance systems by emphasising pre-existing interdependencies. Both the oyster aquaculture industries based in the Thau lagoon (France) and the Lower Hawkesbury Estuary (Australia) then later suffered from a series of OsHV-1 disease outbreaks. Such risks and their management led to adapted (or maladapted) forms of governance that reorganise local actors and industryrelated institutions interactions [104]. Studying the consequences of the first QX disease outbreak allows for exploration the evolution of risk governance and the role of collaboration and information. This disease outbreak highlighted the interdependencies between oyster farmers and government agencies and in so doing, catalysed greater collaboration between these actors. More specifically, NSW oyster farmers, including those in the Hawkesbury (Broken Bay) worked with the State Government to develop a common oyster industry aquaculture strategy [105]. Oyster farmers credit the QX crisis as the catalyst for developing new social norms and practices that would lead to a more sustainable industry [72]. This process not only helped farmers to build collective identity and resilience but to set up systems-both formal and informal- to better manage other risks that might beset them in the future. This included a new local legislative requirement, SEPP62, for all developments that could have estuarine impacts $[104,127]^{2}$ Such proactive collaborative engagement, supported by best available information, has led to the NSW Oyster industry being seen by many catchment, government and community leaders as 'stewards' of the estuary and their oysters as the 'canaries of the catchment' [106], providing early warning on catchment, estuary and marine environment health [72]. However, the 2014 OsHV-1 oyster disease outbreak in the Lower Hawkesbury estuary, has demonstrated continuing fragility and vulnerability of the oyster aquaculture industry, despite the oyster farmers' capacity to self-organise and take a key role in collective estuarine governance $[107,108]$.

In Thau and the Lower Hawkesbury, risks and shocks to these estuaries have created new flows of information which transformed the governance of these estuaries. These information flows may reinforce or restructure stakeholder interactions within estuary governance regimes. For example, in response to the 2004 oyster QX disease outbreak, Lower Hawkesbury oyster farmers collaborated with researchers, with support from the Hornsby Shire Council and the NSW government to undertake intensive sampling and monitoring of the impacts of QX disease [72, 109]. Collectively, the Oyster farmers then also developed an information system-an Environmental Management System (EMS) [110]with the support of a boundary organisation (Oceanwatch), based on a risk management framework to support their management of the estuary. These information systems enabled oyster farmers to reassert a stewardship role and to engage more actively in the management of the estuary. In contrast, in the governance of the Thau Basin, oyster disease outbreaks and other threats (e.g. poor water quality events due to catchment flooding), led to alternative actors mobilising. Specifically, the French State planning apparatus was mobilised, and the development of Government and research-driven information management systems were deployed to monitor and provide early warnings to stakeholders, including oyster farmers. However, unlike the information systems developed in the Lower Hawkesbury, at the community level, by the farmers themselves, there is evidence that these larger information systems in Thau (e.g. OMEGA Thau, see Ref. [29] are not developed

\footnotetext{
${ }^{2}$ See in particular Section 3A: https://www.legislation.nsw.gov.au/\#/view/ EPI/2000/473/part3a This particularly leads to consideration of the NSW Oyster Industry Sustainable Aquaculture Strategy [119], see also [120].
} 
specifically for all of the perceived needs of Thau's oyster farmers [31, 55]. Furthermore, these information systems have not created a community empowered as 'estuary stewards' as in Australia. They have, however, created further legitimacy for the SMBT as described in the earlier discussion sections.

In the New Caledonian Thio estuary, environmental risks from heavy rainfall events created conflicts that led actors to reinvent themselves and change institutional configurations. Conflict plays an important role in the evolution of governance systems. Beunen et al. ([36]: 27-28) argue that governance paths are paved with conflict and shaped by indefinite competition between discourses. Thio illustrates the role specific risks in crystallising these conflicts and how this in turn can lead to the reconfiguration of a governance system. For example, in 2013, rainfall events of exceptional intensity followed one after another, several months apart (cyclone Freda in January and heavy rains in June) in the municipality of Thio. Floods and landslides caused material damage in localities at the bottom of slopes and to the rivers downstream. The population of Thio mobilised quickly in response to these hazards by blocking access to the three mining sites of the commune (Plateau, Fir Camp, Dothio). This mobilisation resulted in the drafting of a claim book and the creation of an inter-ethnic collective which included employees of the nickel company (SLN). Formal governance arrangements followed with the signing of a memorandum of understanding by the collective, the town hall, the Southern Province, the government of New Caledonia and the SLN. The collective was later formed into an association whose name, Chava xua, means "take care of one's house/community" in xârâcùù language. In addition, a Simplified Shareholding Company (SAS) was created to organize the interface between SLN and local contractors on the maintenance and environmental rehabilitation projects discussed under the agreement. This mobilisation of stakeholders and reconfiguring of the governance system towards a more collective form of interaction also led to the development of new ways of working and associated norms.

In summary, all three cases illustrate how actors' responses to systemic risks and their impacts may shape and evolve estuary governance processes.

\subsection{Discussion theme 4: inciting collective action and crystallising norms}

As alluded to in the previous sections, adaptability is a fundamental part of evolutionary governance. Actors, environments, institutions and configurations continually change and governance systems must adapt to persist. Within the context of spatial planning, ([111]: 167) points to a paradox that a system "whose main purpose is to plan for change is underpinned by structures which impinge on capacity for change", a similar assertion could be made about many estuary governance systems. This has led to the question of to what extent evolutions in governance can be intentionally opened up by actors through changes in their discourse and aspirations for desired configurations of collective estuary governance action. Governance evolution in all three estuaries was influenced by particular discourses (see Appendix for a summary) and described in part in the last sections, with some cutting through in the times of crisis as previously noted. However, 'non-crisis' time discourses about future potential configurations of collective action and how particular sets of norms could be intentionally crystallised to guide future evolutions of estuarine governance have also been analysed. Specifically, in the Lower Hawkesbury, an initial discourse on the need for estuarine 'risk governance', pushed largely by one influential local government official, was collectively developed and enshrined through the Lower Hawkesbury Estuary Management Plan [91], based on the Australian/New Zealand Risk Management Standard (AS/NZS 4630:2004). However, following the almost complete implementation of this plan in the following years, its instigators have been debating what should replace it. Specifically, a discourse around 'standards-based governance' has emerged as one way of enhancing adaptability and guiding the evolution of estuary governance towards specific socio-ecological constraints and more effectively managing estuarine risks. The current discourse is that, if used well, standards-based governance can open up boundaries by improving matches between information and coordination of stakeholders and multiple levels of governance [100]. This in turn encourages the development of new governance relationships across spatial and jurisdictional boundaries. They propose that two such standards provide methods to achieve this: the international risk assessment and management standard (ISO 31000) and bowtie analysis (ISO 31010). ${ }^{3}$

Extending discourse and actor analysis into the networks beyond the estuarine case studies, there is evident cross-country learning about potentially valuable governance configurations that can be incited through the use of particular tools. Here, the Lower Hawkesbury actors have noted that [112] provide an example of the combination of risk assessment and bowtie analysis and how they have been used together to improve risk governance in a freshwater system. These authors demonstrate for the Great Lakes ecosystem in North America the importance of analysing the entire system of management operating at different jurisdictional levels. Using these two methods they analysed 137 federal, provincial and state management controls. They identified potential strengths and weaknesses in the management system [112] that needed to be addressed to improve the governance and management of the Great Lakes. Equivalent studies for estuaries and coasts in Australia are currently being developed (e.g. Ref. [64]) but actors acknowledge that such intentional reconfiguring of governance systems remains a much needed area of interdisciplinary research, including how such systems may be co-owned (e.g. found to be appropriate), co-constructed (e.g. to ensure legitimacy of use and validity of information), and co-evolved as the boundaries of governance and the actors within them reassemble over time to ensure usefulness.

This networked policy learning links areas of EGT with the literature on policy (or whole governance system configuration) translation and mobility (e.g. Refs. [113-115,123]). For such policy or governance systems ideas to travel, it is usual to find key actors (e.g. policy entrepreneurs, champions or even artefacts such as information systems) who have inserted the idea into a number of required arenas for collective action to be instigated. In the Thau basin, one of these key ideas has been that of 'territorial coherence', stemming from other regions of France where an understanding and maintenance of landscapes and their amenity (including villages, vines and oyster farms) has been promoted. Such an idea has been translated to a supportive discourse around the integration of multiple planning frameworks previously discussed, and more importantly, provided the social impetus for collaboration and support of the role of the SMBT broker organisation. Central to its effective translation was its capacity for many actors in the basin to adhere to a central, shared vision - one of 'coherence' where each of their core values and historical ways of living in the basin would be maintained and fit in with others [2,109]. Representation of these values and spatial placement of activities on maps and information systems allowed the past norms of territorial development to be visualised. From this, new collective action around developing greater coherence where conflicts were identified became possible and the basis for co-evolution of these planning systems into a more integrated basin-wide governance system.

\footnotetext{
${ }^{3}$ Risk assessment and management determines the likelihood of not achieving the management objectives of a governance policy(s) for a social-ecological system [121]. It identifies what components are at risk of not meeting the management objectives, why it is at risk (i.e. the risk factors) and how these risk factors could be addressed (i.e. risk management). Bowtie analysis then evaluates the performance of the management systems in place in addressing the identified risk factors to determine the systems' ability to achieve the management objectives and therefore their success or failure in implementing a policy of governance [121].
} 


\section{Conclusions and perspectives}

Drawing on the analysis presented in the previous section, the current section infers some concluding reflections on co-evolution processes in estuarine governance. Key perspectives are drawn from extending the three focal areas used to compile the meta-dataset for the three case studies (as outlined in the Methodology section: $i$ ) scales and levels; $i$ ) roles and information flows; and iii) stakeholder perceptions and discourses.

Firstly, a focus on the scales and levels associated with estuary governance offers a new empiricism for understanding the evolution of boundaries and the boundary work that underpins them. Ref. [53] explicitly recognise the role of analysing boundary formation, maintenance, and change in understanding the evolutionary nature of governance. As places centred around land-sea interactions, the materiality of estuaries and the ecological scales on which they function point to the ambiguity of 'natural boundaries' that, from the perspective of governance, are often masked by a discursive land-sea divide. Such ambiguity has impacted the evolutionary directions of governance processes and has raised the question as to whether actors in these estuarine spaces already have a sense, and language, of an integrated land-freshwater-sea system (coastal/estuarine zone) or whether they are yet to develop one. In addition, the boundaries around the environmental scales of estuaries are also evolving. This is because resource managers are increasingly widening their scope from 'ridge to reef', to 'ridge to reef to ocean', where sea planning is integrated with land-based territorial planning.

Because of the diversity of different interests and governance structures embedded in these land-sea spaces, estuary governance systems often undergo processes of fragmentation: the splitting of governance systems into siloed components such as land use planning, marine planning, economic development and natural resources management, where in each politics, economics, law, science and understandings of the world are contested. Our analysis suggests that moving towards an evolutionary understanding of estuary governance necessitates an appreciation of how these differentiated and fragmented systems are being re-hybridised and the struggles between, and boundaries of, components are being negotiated. For this move to be realised, drawing on both complementarities in EGT understandings of functional differentiation (e.g. Ref. [36]) and fragmegration (integration/fragmentation) processes in multi-level governance theory could provide a platform for future research (e.g. Refs. [41,116].

Secondly, reflecting on roles and information flows, from the case studies, it is apparent that brokering and coordinating organisations play a key role in steering estuarine governance systems. In many cases, mathematical models or information systems (e.g., observatories) themselves become new actors in estuarine governance systems around which evolutions in estuarine governance and associated forms of collective action are created. This was particularly the case with the environmental management systems in the NSW estuaries and the pivotal role of the SMBT, with its associated models and platforms for capturing, organising and disseminating territorial intelligence [104]. In terms of perspectives for other estuaries around the world, new coordinating actors, information systems and structures may be required to navigate the changing levels and scales of governance. For example, information systems linked to the Chava xua association in Thio could play a critical role in evolving this estuary's future governance.

Thirdly, analysis of the three estuary cases suggests that stakeholder perceptions and discourses play a fundamental role in 'place-making' and delineating (new) boundaries where the discourses of particular actors - often brokering or key stakeholder groups such a key local councils and the oyster industry in the Hawkesbury, the SMBT in Thau and the Chava xua and SLN in Thio - assume dominance and power in driving collective action or promoting specific governance models (e.g. risk-based or standards-based governance) that leads to particular governance evolutions. Specifically, those that support the maintenance and effective positioning of these organisations as actors that must be considered in estuarine-focussed decision-making. Findings from the comparative case analysis suggest that cultural evolutions, past governance arrangements and settlement patterns do indeed change perceptions of estuaries as a boundary space and their associated images of history. Such processes create path dependencies which in turn shape the roles, information flows, stakeholder perceptions and discourses central to estuary governance. New ideas and discourses with an ability to connect to these pasts and identify both the best of what to keep and how to navigate changes in relationships and responsibilities of actors in the estuarine governance systems, were taken up in the three cases. It should be noted, however, that unless powerful actors choose to enrol and empower other (marginalised) actors, the nature of these processes can often exclude already marginal resource users [117] or further entrench the power of already powerful actors.

The exploration of findings from the three case-studies presented in this paper have allowed us to understand and contrast the ways in which different estuarine governance systems may co-evolve through the actions of different actors, including information systems or models. In each of these cases, scales and levels, values and perceptions of risks, as well as the lived experience of crisis events were demonstrated to have critical, inter-connected effects on the co-evolution of governance arrangements. The co-evolutions that were identified have typically led to greater collaboration, information flow and coordination. Whether such processes are present, or may be instigated, in other estuarine governance systems and how particular co-evolutions can be incited in noncrisis situations remain important questions for future research and practice.

\section{Acknowledgements}

All authors receive salary, financing and/or support from their organisational affiliations. The development of this article was supported by discussions within the COST Action CA15217 - Ocean Governance for Sustainability - challenges, options and the role of science, supported by COST (European Cooperation in Science and Technology). Participation in these discussions was financed by an Australian National University COST Action grant. Research feeding into the manuscript was funded by the French Government (Fonds Pacifique), European Commission, CSIRO and the General Sir John Monash Foundation. The lead author (K.A. Daniell) is a member of the Initiatives of the Future of Great Rivers and a Director of the Peter Cullen Water and Environment Trust. Thank you to all colleagues and communities who have supported our work and their own estuary governance processes over the past decades in the Hawkesbury, Thau and Thio. 


\section{Appendix}

Table A1

Estuary Case Study Comparison

\begin{tabular}{l}
\hline Case Studies \\
\hline 1. Scales and levels \\
1.1. Location and topography (What \\
type of coastal formation is this? Where \\
is it located?)
\end{tabular}

1.2. Levels of governance (What are the relevant administrative scales?)

1.3. Institutional mechanisms (What are the governance structures in place for this estuary such as laws, decision processes, engagement mechanisms/ management committees?)

\subsection{Natural assets and uses (What are the principal uses and values for the estuary?)}

\subsection{Planning extent (What does estuary planning cover: the extended basin, reefs, catchment etc. \& what issues e.g. land development, water management, industry regulation/support, environmental quality) \\ 2. Roles and information flows \\ 2.1. Stakeholders/beneficiaries involved (Who are the key stakeholders involved in the estuary/those who benefit from it?)}

2.2. Historical evolution (How have the uses, governance and actors of the estuary evolved?)

2.3. Information sharing mechanisms (How is knowledge about the estuaries distributed? What types of information are valued and by whom?)
Lower Hawkesbury, NSW, Australia

Thio Estuary, New Caledonia

East coast of Australia, northern edge of Sydney, semi-mature tide dominated drowned valley estuary (estuary).

Community (farming, fishing, representatives on management committees); Local government- Councils, regional (e.g. Lower Hawkesbury estuary management plan committee); State Government (Fisheries, owner of water agency -Sydney Water, LLS); Federal Government (EPBC Act).

Lower Hawkesbury Estuary Management Committee, Local Environment Plans (LEPs), Development Control Plans (DCPs), EPBC Act, NSW Environmental Planning and Assessment (EPA) Act, 1979; State Environmental Planning Policy (SEPPs), Regional Environmental Plans; Water Management Act 2000; National Parks and Wildlife Act 1974 (NSW) Local Land Services Act 2013; Environment Operations Act 1999; Threatened Species Conservation Act 1995; Fisheries Management Act 1994.

Oyster farming; fishing (passive and engine); boating \& water activitiesrecreation (recreational swimming sites); scenic amenity; cultural heritage; adjoining land-based urban development; bird watching (migratory birds); Beaches; seagrasses; mangroves; mudflats; freshwater holes; wetlands.

Lower river basin including tributary catchments (but excludes coastal catchments): multi-risk focus (physical, governance, economic) but main ability for implementation is through local government mechanisms.

Oyster farmers, boat owners/marinas, commercial and recreational fishers, local residents (scouts, school students, water sports), tourists, water agency, indigenous community.

Previously more oyster farmers. Now due to disease only 3 businesses remain. Also due to recent government fisheries reforms, there have been changes to the number of commercial fisheries operating in the estuary. Significant Increase of upstream urban development and recreation. From individual council level estuary management committees and plans to a multi-council committee and plan.

Through planning documents and web portals; EMS; through local social networks and conferences; Council's annual reports; water quality report health cards; Council's website and youtube videos; community education events run by Council and other government agencies; public talks at libraries; free guided bushwalks and Estuary tours; through community groups.
Southern Province, West Coast, mouth of the Thio River $180 \mathrm{~km}$ from Noumea, included in Xârâcùù customary area).

Southern Province Community/local associations; Southern Provincial Government; the New Caledonian government, responsible for the protection and prevention of pollution; $f$ reshwater management partially depends on French municipalities' code, excluding rights on customary land.

The governance of Thio rests with the government of the Southern Province (which encompasses the entire river). There has been an increasing push for local governance.

The indigenous and clan-based Kanak dimension came to the foreground in 1996 , and more recently in the negotiations about the possible restart of mining in the southern part of Thio (called 'the forgotten coast') and after two important rain events in 2013 an interethnic association "Chava xua" was formed.

Nickel mining (nickel extraction is very water intensive); local agriculture and small fisheries; $\mathrm{w}$

ater, including in the estuary, has important cultural value to local Kanak tribes; environmental water, a concern for local NGOs and as a buffer for extreme events (e. g. drought and cyclones); land-based urban development.

Extended basin, reefs, catchment industry regulation including mining, agricultural soils. Freshwater management.

National Nickel Mining Syndicat (SLN), mining Trade unions, Kanak tribe of St. Philippe, NC environmental associations. Local association of Thio citizens (Chaava xua). Local residents (70\% of whom are Melanesian).

Largely influenced by history of mining which commenced in 1880). Previously influenced by colonial agriculture (ranching) and traditional horticultural practices. Flood events in 2013 incited governance changes to reduce risks (e.g., landslides) with an interethnic association forming "Chava xua". A Simplified Shareholding Company (SAS) was also created to organize the interface between SLN and local maintenance and environmental rehabilitation contractors. After the signature of the local agreement, it raised the question of the follow-up of the necessary restoration and environmental maintenance work. The meetings organised on the ground in the affected areas, implied the signatories of the agreement and also the Nickel Fund, public establishment of New Caledonia whose mission is the rehabilitation of sites degraded by mining activity.
Thau Lagoon, France

South of France (Languedoc-Roussillon), stream-fed semi enclosed karstic lagoon connected to the Mediterranean sea by two small inlets.

Community (fishers and oyster farmers); Municipal Governments (15 different townships) responsible for urban development planning; Intercommunalities (unified representation for these 15 townships); Regional (SMBT); National (State planning directive); European (Natura 2000).

DCE (Water law); SAGE (water plan cobuilt with important local stakeholders); SCOT : an integrative planning and management tool thatencourages the increasing urbanisation of already urbanised areas in the south of the basin (Sete, Frontignan, Balaruc-les-Bains) and the conservation of natural and agricultural spaces in the northern part of the basin; CGI (integrated management contract); Natura 2000 (biodiversity/conservation planning); SMVM (Sea planning); SLGRI (Flood planning)

Oyster farming; fishing; agricultural activities (viticulture, horticulture and livestock farming); natural environment of the garrigues (hiking, hunting etc ...); tourism - picturesque towns and villages (particularly Sete); scenic landscape; some leisure boating; local produce (e.g. Picpoul de Pinet with oysters); beaches.

Collective management of the estuary covers most of the basin and near-sea area, including urban development and redevelopment.

Oyster farmers, fishers, leisure boaters, tourists, tourism industries, residents, public servants, hunters, environmental NGOs and associations (LPO and CPIE Thau).

Local councils created a first catchmentwide organisation that couldn't legitimize itself. Now SMBT has gained legitimacy (catchment jurisdiction) by including stakeholders in planning. It has been so successful over the past decade that it has been given further responsibility over coordinating local flood planning.

Many actions of SMBT (participatory planning, conferences open to publichtt p://oramaritima.fr/), collaborative mapping, mapping of ecosystems services based on local actors' perceptions, models included in Decision Support Systems (e.g. OmegaThau), territorial information system 
Table A1 (continued)

Lower Hawkesbury, NSW, Australia

Case Studies
3. Actor perceptions and discourses

3.1. Focal governance interests (What are the key issues of importance for governance in the estuary? Perceived threats/risks?)

3.2. Influential discourses (What have been the key discourses that have shaped the evolution of governance? Where did the originate and who used them to bring

\subsection{Future scenarios and} development options (What are the best options for evolving, coordinated estuary governance in light of these

3.4. Efficacy of governance (What has worked and where do the biggest governance challenges still lie? What interactions/integration are insufficiently managed?) about change?) challenges?)

Water quality (due to urban run-off as a result of increased impervious surfaces, upstream agriculture and cattle run-off, harmful algae blooms, WWTP discharges, pollution i.e. plastics); oyster diseases; urban/industrial development climate change adaptation;invasive species (animals and plants-weeds), lack of management coordination; i ncreased motor boating and water-sport activities (boat wash/foreshore erosion); reduction/impact on macrophytes (seagrasses, saltmarsh and mangroves); Environmental protection and scenic amenity - protecting the estuary from development (residents and environmentalists) - Natural Resource Management portfolio in Council; oyster farmers as estuary stewards (OISAS strategy); lack of integrated governance (Councils, CMA); s

tandard land use zonings for LEPs across the NSW coastline, risk management and standards and a better basis for managing estuaries (Councils, NSW Govt); Integrated Coastal Management (Councils, NSW

Govt); vulnerability to climate change and population growth.

Development of a planning regime based on a NRM standard. Estuarine region planning fully integrated with development and coastal planning. Development of an overall management plan for the entire Hawkesbury Estuary, coastal zone and river systems. Standard procedures and legislation across all Local Government Areas.

Change in level of estuary Governance was useful for coordination. Renewal of planning is needed. Climate change, development and some risks (e.g. disease) still insufficiently managed.

lack of sustainable development planning strategy.

Development applications not being properly assessed. Lack of compliance post approval, poor implementation of DCPs. Federal, state and local legislation overlaps and overwrites each other

3.5. Implementation requirements (What are the key resources/barriers to overcome?)

Thio Estuary, New Caledonia

Water quality (due to nickel mining run-off and mining related erosion); hypersedimentation of river and of coral reefs;water availability and over extraction during drought; flooding in the event of cyclones; ettlements on slag fills and barrier beach.

The issue of monitoring the necessary restoration and environmental maintenance work in the river revealed two non-exclusive narrative options:

(1) technical follow-up of the work done or

(2) an inclusive political logic of local citizenship. The local association, Chava xua's strategy combined collective action on the ground, aimed at putting pressure on the actors of the ecological restoration, in particular the SLN, and a political and moral discourse, enjoining the SLN to be consistent with their branding as a "New Caledonian company"

Better articulations between institutional managers and between institutional and formal and informal local managers. Planned debates on catchment basin management especially as the New Caledonian government has launched a national public engagement program to build a national water policy.

Adoption of standard procedures for layouts taken into account geo-physical and social issues (dredging, technical structures on the river and on the estuary as well as management of agricultural and residential areas, human displacements, etc.).

Estuary governance is still a very important challenge.

There is a better account/consideration of environmental damages on residents. Regarding residents, biggest governance challenges lie in the management of flooding and hypersedimentation of all the catchment basin that impact their agricultural, fishing and housing areas. The action of civil society at large has revealed powerful (if not sufficient) to push SLN and public authorities to fulfill its obligations in terms of social responsibility and environmental management New Caledonia's relationship to Nickel as an engine of economic growth and how this fits with other resource uses. There is also wider uncertainty about the political provincial and federal structures of New Caledonia.

Seeing the estuary \& catchment as a focus of governance rather than mangroves or fishing grounds or nearby settlements as is

the case now.
Thau Lagoon, France

Water quality (due to fertilizer and pesticide use, but also low level of sewage treatments in coastal communities due to flash floods and population variations across seasons and general increase); strong urban pressure; progressive "disappearance" of agricultural activities; maintenance of character of historic towns and settlement patterns (e.g. amenity of vineyards and lagoon landscapes with oyster plots).

Territorial coherence and maintenance of aesthetic landscapes (vines, oyster farms, old towns) - local residents/industry reps. Need to modernise communication and collective governance systems to respond to challenges/risks (researchers, government officials). On water quality: 1) the importance of conservation spaces and buffers for improving run-off quality; 2) how to control population growth in the whole basin and subsequent pollution though development restrictions; or 3) limiting boat traffic and direct pollution in the lagoon.

Supporting the development of more locallevel stakeholder groups that can work in an organised fashion with the SMBT and have information developed for them that meets their (and the rest of the basin's) needs.

One way forward is the social evaluation of the presence of ecosystem services on a territory and to map them (ongoing project).

A project of a Territorial Living Lab is currently being investigated.

SMBT has been seen as an important an effective planning broker/coordinator, to the extent that it has been given further responsibilities in flood management. Links with local residents/oyster farmers and winegrowers are still needed to build stronger community support/awareness of plans and responsibilities. Bi-directionality of information exchanges might be enhanced.

Human and digital resources for broaderscale participation and stakeholder support. Overcoming a lack of political will. responsibilities. Lack of (financial) resources 
Table A2

Estuary Case Study Author contributions

\begin{tabular}{|c|c|c|c|}
\hline Case Studies & Lower hawkesbury, nsw, australia & Thio estuary, new caledonia & Thau lagoon, france \\
\hline 4.1. Individual interviews with stakeholders & 54 & 60 & 78 \\
\hline 4.2. Workshops attended & $\sim 90$ & 8 & 12 \\
\hline 4.3. Meetings attended & $\sim 110$ & 12 & 25 \\
\hline 4.4. Workshops organised & 7 & 10 & 10 \\
\hline 4.6. Number of authors with a role in Governance & $\begin{array}{l}\text { Direct Managers: } 2 \text { (17 years \& } 10 \text { years service) } \\
\text { Researchers: } 4\end{array}$ & $\begin{array}{l}\text { Direct Managers: } 0 \\
\text { Researchers: } 4\end{array}$ & $\begin{array}{l}\text { Direct Managers: } 0 \\
\text { Researchers: } 5\end{array}$ \\
\hline
\end{tabular}

\section{Appendix A. Supplementary data}

Supplementary data to this article can be found online at https://doi.org/10.1016/j.marpol.2019.103704.

\section{References}

[1] R.B. Wallace, H. Baumann, J.S. Grear, R.C. Aller, C.J. Gobler, Coastal ocean acidification: the other eutrophication problem, Estuar. Coast Shelf Sci. 148 (2014) 1-13.

[2] B. Rulleau, H. Rey-Valette, Forward planning to maintain the attractiveness of coastal areas: choosing between seawalls and managed retreat, Environ. Sci. Policy 72 (2017) 12-19.

[3] I. Iniesta-Arandia, M. García-Llorente, P.A. Aguilera, C. Montes, B. Martín-Lopez Socio-cultural valuation of ecosystem services: uncovering the links between values, drivers of change, and human well-being, Ecol. Econ. 108 (2014) 36-48.

[4] L.-E. Ruoso, R. Plant, P. Maurel, C. Dupaquier, P. Roche, M. Bonin, Reading ecosystem services at the local scale through a territorial approach: the case of Peri-urban agriculture in the Thau lagoon, southern France, Ecol. Soc. 20 (3) (2015) 11, https://doi.org/10.5751/ES-07694-200311.

[5] S. Mathe, H. Rey-Valette, Local knowledge of pond fish-farming ecosystem services: management implications of stakeholders' perceptions in three different contexts (Brazil, France and Indonesia), Sustainability 7 (2015) 7644-7666.

[6] N. Lazarow, R. Souter, R. Fearon, S. Dovers, Coastal Management in Australia: Key Institutional and Governance Issues for Coastal Natural Resource Management and Planning, Cooperative Research Centre for Coastal Zone, Estuary and Waterway Management (Coastal CRC) Indooroopilly Sciences Centre, Brisbane, 2006, p. 136.

[7] H. Rey-Valette, M. Antona, Gouvernance et gestion integree du littoral : l'exemple des recherches françaises, VertigO - la revue electronique en sciences de l'environnement [En ligne] 9 (1) (2009). http://journals.openedition.org/verti go/8455.

[8] J.G. Alvarez-Romero, R.L. Pressey, N.C. Ban, K. Vance-Borland, C. Willer, C. J. Klein, S.D. Gaines, Integrated land-sea conservation planning: the missing links annu, Rev. Ecol. Evol. Syst. 42 (2011) 381-409.

[9] T.M. Carvalho, T. Fidelis, The relevance of governance models for estuary management plans, Land Use Policy 34 (2013) 134-145.

[10] T. Fidelis, T. Carvalho, Estuary planning and management: the case of Vouga Estuary (Ria de Aveiro), Portugal, J. Environ. Plan. Manag. 58 (2015) 1173-1195 7 pp.

[11] T. Stojanovic, N. Barker, Improving governance through local coastal partnerships in the UK, Geogr. J. 174 (2008) 344-360, 4 pp.

[12] J.M. Rybczyk, J.W. Day Jr., A. Yañez-Arancibia, J.H. Cowan Jr., Global climate change and estuarine systems, in: J.W.J. Day, B.C. Crump, W.M. Kemp, A. YanezArancibia (Eds.), Estuarine Ecology (Second, Pp. 497-518). Hoboken, WileyBlackwell, New Jersey, 2013.

[13] UNSW Water Research Laboratory, Estuaries and climate change (fact sheet). Coast adapt. https://coastadapt.com.au/sites/default/files/factsheets/T3I6_Estua ries_and_climate_change_0.pdf, 2016.

[14] O.R. Young, The Institutional Dimensions of Environmental Change: Fit, Interplay, and Scale, MIT press, 2002

[15] D. Cash, W.N. Adger, F. Berkes, P. Garden, L. Lebel, P. Olsson, L. Pritchard, O. Young, Scale and cross-scale dynamics: governance and information in a multilevel world, Ecol. Soc. 11 (2) (2006).

[16] K.A. Daniell, O. Barreteau, Water governance across competing scales: coupling land and water management, J. Hydrol. 519 (2014) 2367-2380.

[17] R. Boyd, R. Dalrymple, B.A. Zaitlin, Classification of clastic coastal depositional environments, Sediment. Geol. 80 (3-4) (1992) 139-150.

[18] P.S. Roy, R.J. Williams, A.R. Jones, I. Yassini, P.J. Gibbs, B. Coates, R.J. West, P. R. Scanes, J.P. Hudson, S. Nichol, Structure and function of south-east Australian estuaries, Estuar. Coast. Shelf Sci. 53 (3) (2001) 351-384.

[19] M. Imperial, Institutional analysis and ecosystem-based management: the institutional analysis and development framework, Environ. Manag. 24 (4) (1999) 449-465.

[20] L.P. Hildebrand, Cooperation in the coastal zone, Ocean Coast Manag. 25 (3) (1994) 233-235.

[21] J. McKenna, A. Cooper, A.M. O'Hagan, Managing by principle: a critical analysis of the European principles of integrated coastal zone management (ICZM), Mar. Policy 32 (6) (2008) 941-955.
[22] G. Wescott, Disintegration or disinterest? Coastal and marine policy in Australia, Environ. Policy Fail. Aust. Story (2012) 88-101.

[23] K. Van Assche, A.-K. Hornidge, A. Schlüter, N. Vaidanu, H. Toonen, Governance and the coastal condition: towards new modes of observation, adaptation and integration, Mar. Policy (2018) (this Special Issue).

[24] J.L. Ticehurst, R.A. Letcher, D. Rissik, Integration modelling and decision support: a case study of the coastal lake assessment and management (CLAM) tool, Math. Comput. Simulat. 78 (2-3) (2008) 435-449.

[25] R.A. Kelly, W.S. Merritt, in: B. Manos, K. Paparrizos, N. Matsatsinis (Eds.), The Role of Decision Support Systems (DSS) in Planning for Improved Water Quality in Coastal Lakes, 2011.

[26] T.J. Miller, J.A. Blair, T.F. Ihde, R.M. Jones, D.H. Secor, M.J. Wilberg, FishSmart: an innovative role for science in stakeholder-centered approaches to fisheries management, Fisheries 35 (9) (2010) 424-433.

[27] M. Eustis, The Oyster Futures Program, 9 March 2017, online at:, Chesepeake Bay Magazine, 2017 https://www.chesapeakebaymagazine.com/talkofthebay/ 2017/3/9/the-oyster-futures-program.

[28] J. Barde, T. Libourel, P. Maurel, J.C. Desconnets, N. Mazouni, L. Loubersac, A metadata service for managing spatial resources of coastal areas, in: D. Green (Ed.), Coastal and Marine Geospatial Technologies. Coastal Systems and Continental Margins, vol. 13, Springer, Dordrecht, 2010.

[29] R. Plant, P. Maurel, O. Barreteau, Y. Bertacchini, The role of territorial intelligence: the case of the Thau territory, Southern France., in: V.R. Squires, H. M. Milner, K.A. Daniell (Eds.), (2014). River Basin Management in the TwentyFirst Century: Understanding People and Place, 2014, pp. 446-466.

[30] C. Dupaquier, A. Desbrosse, P. Maurel, R. Plant, L.E. Ruoso, J.P. Roussillon, Apports de l'imagerie Pleiades a la gestion integree des zones côtieres, Numero special Pleiades Days, Rev. Fr. Photogrammetrie Teledetection 208 (2014) 45-50, 2014.

[31] N. Paget, K.A. Daniell, A. Rubio Zuazo, O. Barreteau, Environmental information sharing: a means to support the legitimization of oyster farmers' stewardship over water quality management in NSW, Australia, Nat. Resour. Forum 40 (1-2) (2016) 21-36.

[32] J.P. Tonneau, P. Maurel, Satellite imagery, a tool for territorial Development, in: N. Baghdadi, M. Zribi (Eds.), Land Surface Remote Sensing in Urban and Coastal Areas, ISTE-Elsevier, Londres, 2016, ISBN 978-1-78548-160-4, pp. 101-140.

[33] P. Lemoisson, J.P. Tonneau, P. Maurel, L'intelligence territoriale dans le bassin de Thau: un observatoire pour penser et piloter l'action, in: Torre Andre, Vollet Dominique (Eds.), Partenariats pour le developpement territorial, Ed. Quae, Versailles, 2016, pp. 59-73. Update Sciences \& technologies).

[34] K. Barclay, A. McIlgorm, N. Mazur, M. Voyer, A. Adjunct, S. Schnierer, A. M. Payne, Social and economic evaluation of NSW coastal aquaculture. https ://www.uts.edu.au/sites/default/files/fass-report-social-economic-evaluatio n-nsw-coastal-aquaculture.pdf, 2016.

[35] M. Voyer, K. Barclay, A. McIlgorm, N. Mazur, Connections or conflict? A social and economic analysis of the interconnections between the professional fishing industry, recreational fishing and marine tourism in coastal communities in NSW, Australia, Mar. Policy 76 (2017) 114-121.

[36] R. Beunen, K. Van Assche, M. Duineveld, Evolutionary Governance Theory, Springer International Publishing, 2016.

[37] J.P. Voß, Governance of transformation in electricity systems: problems, context conditions, and the potential of evolutionary governance for shaping sustainable transformation in Germany and The Netherlands. http://citeseerx.ist.psu.edu/vie wdoc/download?doi 10.1.1.195.125\&rep rep1\&type pdf, 1998.

[38] G. Blundo, P.-Y Le Meur, An anthropology of everyday governance: collective service delivery and subject-making, in: G. Blundo, P.-Y. Le Meur (Eds.), The Governance of Daily Life in Africa. Ethnographic Explorations of Public and Collective Services, Brill, Leiden, 2009, pp. 1-38.

[39] N. Rose, Powers of Freedom: Reframing Political Thought, Cambridge University Press, 1999.

[40] M. Dean, Governmentality. Power and Rule in Modern Society, second ed., Sage, London, 2010.

[41] L. Hooghe, G. Marks, Multi-level Governance and European Integration, Rowman \& Littlefield, 2001.

[42] I. Bache, M. Flinders (Eds.), Multi-level Governance, Oxford University Press, Oxford, 2004. 
[43] K.A. Daniell, A. Kay (Eds.), Multi-Level Governance: Conceptual Challenges and Case Studies from Australia, ANU Press, Canberra, 2017.

[44] U. Beck, Risk Society., Sage Publications, Munich, 1992.

[45] O. Renn, Risk Governance: Coping with Uncertainty in a Complex World, Earthscan, 2008.

[46] K. Van Assche, R. Beunen, M. Duineveld, Evolutionary Governance Theory: an Introduction, Springer Science \& Business Media, 2013.

[47] Y. Bertacchini, P. Maurel, P. Deprez, R. Plant, Spatial information \& communication arrangements: a contribution to territorial intelligence, J. Emerg. Trends Comput. Inf. Sci. 4 (1) (2013) 19-28. Jan 2013.

[48] P. Maurel, R. Plant, O. Barreteau, Y. Bertacchini, Beyond IWRM: developing territorial intelligence at the local scales, in: V.R. Squires, H.M. Milner, K. A. Daniell (Eds.), River Basin Management in the Twenty-First Century: Understanding People and Place, CRC Press Taylor \& Francis, 2014, pp. 22-41.

[49] E. Ostrom, Background on the institutional analysis and development framework, Policy Stud. J. 39 (1) (2011) 7-27.

[50] M. Callon, Elements pour une sociologie de la traduction: la domestication des coquilles Saint-Jacques et des marins-pêcheurs dans la baie de Saint-Brieuc, L'Annee sociologique (1940/1948-) 36 (1986) 169-208.

[51] B. Latour, On actor-Network Theory: a few Clarifications, Soziale welt, 1996, pp. 369-381.

[52] J. Law, Actor Network Theory and Material Semiotics, The new Blackwell companion to social theory, 2008, pp. 141-158.

[53] K. Van Assche, R. Beunen, M. Duineveld, An Overview of EGT's Main Concepts. In Evolutionary Governance Theory, Springer International Publishing, 2015, pp. 19-33.

[54] O. Barreteau, P.W.G. Bots, K.A. Daniell, A framework for clarifying "participation" in participatory research to prevent its rejection for the wrong reasons, Ecol. Soc. 15 (2) (2010).

[55] N. Paget, B. Bonte, O. Barreteau, G. Pigozzi, P. Maurel, An in-silico analysis of information sharing systems for adaptable resources management: a case study of oyster farmers, Soc.-Environ. System Model. 1 (1) (2019) 21, https://doi.org/ 10.18174/sesmo.2019a16166.

[56] P. Slovic, The Perception of Risk (Earthscan Risk and Society Series), Earthscan, 2000.

[57] M.B. Van Asselt, O. Renn, Risk governance, J. Risk Res. 14 (4) (2011) 431-449.

[58] G. Midgley, Systemic Intervention: Philosophy, Methodology and Practice. Kluwer/Plenum, New York, 2000.

[59] K.A. Daniell, Co-engineering and Participatory Water Management: Organisational Challenges for Water Governance, Cambridge University Press, Cambridge, UK, 2012.

[60] M.Q. Patton, Qualitative Research, John Wiley \& Sons, Ltd, 2005.

[61] R.K. Yin, Case Study Research: Design and Methods, SAGE publications, Thousand oaks, 2009.

[62] K.L. Astles, Qualitative ecological risk assessment of human disturbances on estuarine habitats, in: K. Astles, G. West, R.G. Creese (Eds.), Estuarine Habitat Mapping and Geomorphic Characterisation of the Lower Hawkesbury River and Pittwater Estuaries, 2010, pp. 32-104. Industry \& Investment NSW, Fisheries Final Report Series No. 117, Nelson Bay.

[63] K. Astles, A. Loveless, Vulnerability assessment of the effects of climate change on estuarine habitats in the lower Hawkesbury estuary, Cronulla, NSW, Australia: NSW Dep. Prim. Ind. 155 (2012).

[64] K. Astles, A. Rubio, P. Coad, Application of Bowtie Analysis and Ecological Risk Assessment to Integrate Fish Habitat Knowledge with Coastal Management Plans for the Hawkesbury Estuary, 2018. Fisheries NSW Research Project collaboration with Hornsby Shire Council, Project No. 110858, Marine Ecosystems Unit, Wollongong, NSW Australia.

[65] P.W. Coad, Predicting Estuarine Algal Blooms Using Artificial Neural Networks, PhD Thesis, University of New South Wales, Sydney, 2012.

[66] P. Coad, W. Wade, R. Letcher, B.C. Phillips, T. Jakeman, An integrated catchment management system for the Shire of Hornsby, NSW, in: 30th Hydrology \& Wate Resources Symposium: Past, Present \& Future, 2006, p. 673 (Engineers Australia, Barton).

[67] P. Coad, B. Cathers, J.E. Ball, R. Kadluczka, Proactive management of estuarine algal blooms using an automated monitoring buoy coupled with an artificial neural network, Environ. Model. Softw 61 (2014) 393-409.

[68] K.A. Daniell, P. Coad, I.S. Ribarova, I. White, N. Ferrand, J. Rougier, A. Tsoukias, P. Haines, N. Jones, A. Popova, S. Burn, P. Perez, Participatory risk management approaches for water planning and management: insights from Australia and Bulgaria, in: 13eme Congres Mondial de l'Eau IWA/13th IWRA World Water Congress, Montpellier, 2008.

[69] K.A. Daniell, I. White, D. Rollin, Ethics and participatory water planning, in: Proceedings of the 32nd Hydrology and Water Resources Symposium: 'H2O09', 30 November-3 December 2009, Australia, Newcastle, 2009, pp. 1476-1487.

[70] K.A. Daniell, N. Ferrand, I. White, P. Coad, I.S. Ribarova, J.-E. Rougier, M. Hare, A. Popova, N. Jones, S. Burn, P. Perez, Co-engineering participatory water management processes: insights from Australia and Bulgaria, Ecol. Soc. 15 (4) (2010) 11. http://www.ecologyandsociety.org/vol15/iss4/art11/.

[71] K.A. Daniell, M.A.M. Costa, N. Ferrand, A.B. Kingsborough, P. Coad, I. S. Ribarova, Aiding multi-level decision-making processes for climate change mitigation and adaptation, Reg. Environ. Change 11 (2) (2011) 243-258.

[72] A. Gordon, Canaries of the Catchment: Exploring the Partnership between Oyste Farmers and Government Actors in Estuary Management, Thesis, The Australian National University, Canberra, 2017.
[73] O. Marinoni, A. Higgins, P. Coad, J.N. Garcia, Directing urban development to the right places: assessing the impact of urban development on water quality in an estuarine environment, Landsc. Urban Plan. 113 (2013) 62-77.

[74] I. La Jeunesse, C. Cirelli, H. Sellami, D. Aubin, R. Deidda, N. Baghdadi, Is the governance of the Thau coastal lagoon ready to face climate change impacts? Ocean Coast Manag. 118 (2015) 234-246.

[75] P. Maurel, Apprentissage collectif pour decider de l'avenir du territoire de Thau: premiers retours d'une approche combinant politique publique et participation. In Conference OPDE 2008 (Les Outils pour Decider Ensemble). https://hal.archi ves-ouvertes.fr/file/index/docid/468559/filename/MT2008-PUB00025203.pdf, 2008 .

[76] P. Maurel, Signes, Donnees et Representations Spatiales: Des elements de sens dans l'elaboration d'un projet de territoire intercommunal.: Application au territoire de Thau, Doctoral dissertation, Toulon, 2012.

[77] P. Maurel, P. Bots, D. Crochet, M. Felter, H. Rey Valette, J.P. Roussillon, J. J. Taillade, H. Van Duijn, Action research in a participatory spatial planning process. The SCOT de Thau (France), in: Territorial Intelligence and Governance Conference, Huelva (Spain), 24-27 october, vol. 2007, 2007, p. 8.

[78] P. Rio, S. Thoyer, Simulation des negociations et intercommunalite sur l'etang de Thau, Econ. Rurale 316 (2) (2010) 3-20.

[79] N. Paget, Facing Threats by Sharing Information for Natural Resources Management, Doctoral dissertation, PSL Research University, Paris, 2016.

[80] R. Plant, J. Walker, S. Rayburg, J. Gothe, T. Leung, The Wild Life of Pesticides: urban agriculture, institutional responsibility, and the future of biodiversity in Sydney's Hawkesbury-Nepean River, Aust. Geogr. 43 (1) (2012) 75-91.

81] D. Richard, M. Garcin, F. Liebault, A. Recking, G. Pitn, C. Sabinot, E. Worliczek, S. Lesimple, M. Bertrand, Y. Gastaldi, T. Burlat, L. Gosset, A. Pidjo, N. Gosselin, Gestion du Passif Minier - Guide methodologique, CNRT Nickel \& Son Environnement, 2017, 79 Pages, 20 fig., 15 tab.

[82] P.Y. Le Meur, Operateurs miniers, gouvernementalite et politique des ressources a Thio, Nouvelle-Caledonie, in: Pacific Science Intercongress Proceedings, 2009. http://webistem.com/psi2009/output_directory/cd1/Data/articles/000166.pdf.

[83] P.Y. Le Meur, Conflict and agreement. The politics of nickel in Thio, New Caledonia, in: C. Filer, P.-Y. Le Meur (Eds.), Local-level Politics and Large-Scale Mines. Between New Caledonia and Papua New Guinea, ANU Press, Canberra, 2017, pp. 157-182.

[84] P.Y. Le Meur, L.S. Horowitz, T. Mennesson, "Horizontal" and "vertical" diffusion: the cumulative influence of Impact and Benefit Agreements (IBAs) on mining policy-production in New Caledonia, Resour. Policy 38 (4) (2013) 648-656.

[85] P.-Y. Le Meur, C. Sabinot, Negocier les savoirs et les valeurs des lieux en NouvelleCaledonie, in: F. Verdeaux, I. Hall, B. Moizo (Eds.), Savoirs Locaux Sous Tension : Entre Politisation Et Naturalisation, Editions Quae, Collection Indisciplines (Forthcoming), 2019.

[86] C. Sabinot, L. Gosset, A. Pidjo, Worliczek, Environmental hazards and local ecological knowledge in Thio upstream and downstream tribes: dealing with climate change, mining industry and subsistence activities in New-Caledonia, in: 7th International Conference on Environmental Future, Humans and Island Environments, Honololu, Hawai, 2018, pp. 16-20 (April).

[87] T.F. Gieryn, Boundary-work and the demarcation of science from non-science: strains and interests in professional ideologies of scientists, Am. Sociol. Rev. (1983) 781-795.

[88] T.F. Gieryn, Cultural Boundaries of Science: Credibility on the Line, University of Chicago Press, 1999.

[89] N. Djanibekov, V. Valentinov, Evolutionary governance, sustainability, an systems theory: the case of Central Asia, in: Evolutionary Governance Theory, Springer, Cham, 2015, pp. 119-134.

[90] G. Midgley, Science as systemic intervention: some implications of systems thinking and complexity for the philosophy of science, Syst. Pract. Action Res. 16 (2) (2003) 77-97.

[91] P. Haines, M. Fletcher, V. Rollason, P. Coad, Lower Hawkesbury Estuary Management Plan, BMT WBM, Pty Ltd, Sydney, 2008.

[92] SMBT, Contrat de Gestion integree 2012-2017, Syndicat Mixte de Bassin de Thau, http://www.smbt.fr/content/contrat-de-gestion-int\%C3\%A9gr\%C3\%A9e, 2012.

[93] L. Gosset, Rivieres engravees a Thio, Nouvelle-Caledonie : vecus et attentes de la population, CRNT Nickel \& Son Environment, 2016.

[94] L. Hooghe, G. Marks, Unraveling the central state, but how? Types of multi-level governance, in: Political Science Series, Institute for Advanced Studies, Vienna, 2003.

[95] K.A. Daniell, A. Hogan, J. Cleary, Breaking down the 'one-size-fits-all' approach to rural and regional policy: enhancing policy initiatives through multi-level governance, in: K.A. Daniell, A. Kay (Eds.), Multi-Level Governance: Conceptual Challenges and Case Studies from Australia, ANU Press, Canberra, 2017, pp. 403-428.

[96] K.A. Daniell, T. Mercer, What remains unwritten? Developing a critical evaluation of multi-level governance and its futures in Australian public policy and politics, in: K.A. Daniell, A. Kay (Eds.), Multi-Level Governance: Conceptual Challenges and Case Studies from Australia, ANU Press, Canberra, 2017, pp. 429-449.

[97] M. Voyer, W. Gladstone, H. Goodall, Methods of social assessment in marine protected area planning: is public participation enough? Mar. Policy 36 (2012) 432-439.

[98] B. Clarke, L. Stocker, B. Coffey, P. Leith, N. Harvey, C. Baldwin, T. Baxter, et al., Enhancing the knowledge-governance interface: coasts, climate and collaboration, Ocean Coast Manag. 86 (2013) 88-99.

[99] L. Stocker, D. Kennedy, R. Kenchington, K. Merrick, Sustainable coastal management, in: R.A. Kenchington, L. Stocker, D. Wood (Eds.), Sustainable 
Coastal Management and Climate Adaptation, Global Lessons from Regional Approaches in Australia, CRC Press, Boca Raton, FL., 2012, pp. 29-56.

[100] K.L. Astles, Linking risk factors to risk treatment in ecological risk assessment of marine biodiversity, ICES (Int. Counc. Explor. Sea) J. Mar. Sci. 72 (2015) 1116-1132.

[101] SMBT, Strategie Locale de Gestion du Risque Inondation, Syndicat Mixte de Bassin de Thau, 2017. http://www.smbt.fr/content/slgri.

[102] J. De Vries, A. Aalvanger, Negotiating differences: the role of social identity in the emergence of institutions for local governance, in: Evolutionary Governance Theory, Springer, Cham, 2015, pp. 291-304.

[103] J.P. Herrenschmidt, P.-Y Le Meur, Politique fonciere et dynamiques coutumieres en Nouvelle-Caledonie et dans le Pacifique. IRD Editions-Province Nord, 2016.

[104] N. Paget, Facing Threats by Sharing Information for Natural Resources Management, PhD Thesis, PSL Research University, Paris, 2016.

[105] DPI, NSW Oyster Industry Sustainable Aquaculture Strategy (Port Stephens), NSW Department of Primary Industries, 2014.

[106] C. Nash, A. Rubio, H. Davies, A. Gietzelt, J. Keating, Monitoring the Canaries of Our Catchments - A Cooperative and Innovative Monitoring Program Quantifying Oyster Performance and Relationships with Estuarine Health. Technical Report Submitted to the Southern Rivers Catchment Management Authority and Bega Coast Oysters, Sydney, 2013.

[107] I. Paul-Pont, O. Evans, N.K. Dhand, A. Rubio, P. Coad, R.J. Whittington, Descriptive epidemiology of mass mortality due to Ostreid herpesvirus-1 (OsHV1) in commercially farmed Pacific oysters (Crassostrea gigas) in the Hawkesbury River estuary, Australia, Aquaculture 422 (2014) 146-159.

[108] R. Whittington, P. Hick, O. Evans, A. Rubio, N. Dhand, I. Paul-Pont, Pacific oyste mortality syndrome: a marine herpesvirus active in Australia, Microbiol. Aust. 37 (3) (2016) 126-128.

[109] A. Rubio, J. Frances, P. Coad, J. Stubbs, K. Guise, The onset and termination of the Qx disease window of infection in Sydney rock oyster (Saccostrea glomerata) cultivated in the Hawkesbury River, NSW, Australia, J. Shellfish Res. 32 (2) (2013) 483-496.

[110] BBOA, Ocean Watch, 5th Draft Environmental Management System, 2011.

[111] J. Hillier, Performances and performativities of resilience, in: Evolutionary Governance Theory, Springer, Cham, 2015, pp. 167-183.

[112] I.F. Creed, R. Cormier, K.L. Laurent, F. Accatino, J. Igras, P. Henley, K. B. Friedman, L.B. Johnson, J. Crossman, P.J. Dillon, C.G. Trick, Forma integration of science and management systems needed to achieve thriving and prosperous Great Lakes, Bioscience 66 (2016) 408-418.
[113] F. Mukhtarov, K.A. Daniell, Diffusion, adaptation and translation of water policy models, in: K. Conca, E. Weinthal (Eds.), The Oxford Handbook of Water Politics and Policy, Oxford University Press, Oxford, 2017, pp. 594-616.

[114] P. Carlile, Transferring, translating, and transforming: an integrative framework for managing knowledge across boundaries, Organ. Sci. 15 (5) (2004) 555-568.

[115] J. Peck, N. Theodore, Follow the policy: a distended case approach, Environ. Plan. A Econ. Space 44 (1) (2012) 21-30, https://doi.org/10.1068/a44179.

[116] J. Rosenau, The governance of fragmegration: neither a world republic nor a global interstate system, Stud. Dipl. 53 (5) (2000) 15-40.

[117] J.F. Brewer, Don't fence me in: boundaries, policy, and deliberation in Maine's lobster commons, Ann. Assoc. Am. Geogr. 102 (2) (2012) 383-402.

[118] A. Helfgott, Operationalising systemic resilience, Eur. J. Operat. Res. (2018), https://doi.org/10.1016/j.ejor.2017.11.056.

[119] NSW DPI, NSW Oyster Industry Sustainable Aquaculture Strategy, third ed., Department of Primary Industries, NSW Government, 2016. https://www.dpi. nsw.gov.au/_data/assets/pdf_file/0006/638250/NSW-oyster-industry-sustai nable-aquaculture-strategy-2016.pdf.

[120] D.M. Ogburn, The NSW Oyster Industry: A Risk Indicator of Sustainable Coastal Policy and Practice, PhD thesis, Australian National University, Canberra, 2011.

[121] R. Cormier, F. Savoie, C. Godin, G. Robichaud, Bowtie analysis of avoidance and mitigation measures within legislative and policy context of the fisheries protection program, Can. Manuscr. Rep. Fish. Aquat. Sci. 3093 (2016) 29 (Ecosystems Management, Gulf Region, Fisheries and Oceans Canada).

[122] P. Collis, The Hawkesbury estuary from 1950 to 2050, in: Estuaries of Australia in 2050 and beyond, Springer, Dordrecht, 2014, pp. 247-257.

[123] M. Evans, Policy transfer in critical perspective, Policy Stud. 30 (3) (2009) 243-268, https://doi.org/10.1080/01442870902863828.

[124] M. Garcin, D. Richard, F. Liebault, A. Recking, G. Piton, C. Sabinot, E. Worliczek, S. Lesimple, M. Bertrand, Y. Gastaldi, T. Burlat, L. Gosset, A. Pidjo, Gestion du passif minier - Rapport scientifique, CNRT Nickel \& Son Environnement, 2017.

[125] N. Paget, K.A. Daniell, A. Rubio Zuazo, O. Barreteau, February. Environmental information sharing: a means to support the legitimization of oyster farmers' stewardship over water quality management in NSW, Australia, in: Natural Resources Forum, vol. 40, Blackwell Publishing Ltd, Oxford, UK, 2016, pp. 21-36. No. 1-2.

[126] G.A. Snedden, J.E. Cable, B. Kjerfve, Estuarine geomorphology and coastal hydrology, in: J.W.J. Day, B.C. Crump, W.M. Kemp, A. Yanez-Arancibia (Eds.), Estuarine Ecology (Second, pp. 41-62). Hoboken, Wiley-Blackwell, New Jersey, 2012.

[127] W.A. O'Connor, M.C. Dove, The changing face of oyster culture in New South Wales, Australia, J. Shellfish Res. 28 (4) (2009) 803-812. 